\title{
Bibliography of Finnish Population Studies 2001-2002
}

\author{
ULLA-MAIJA MATTILA, M.A., Information Specialist \\ The Population Research Institute \\ Väestöliitto, The Family Federation of Finland \\ Helsinki, Finland
}

The bibliography covers the literature on population research published in Finland mainly during 2001-2002. Included are independent publications, articles in periodicals, and nationwide statistics published in Finland as well as studies by Finnish authors published abroad. In general the bibliography excludes nonscientific articles in newspapers and weeklies as well as unpublished reports and academic theses. Also not included are studies presented in proceedings of conferences held in Finland if they are written abroad and treated subjects outside Finland. Neither are comparative studies where Finland not forms a substantial part included in the bibliography. Coverage is less complete in peripheral fields.

In principle the main divisions appearing in the Population Index have been used with added subdivisions better suiting Finnish circumstances. Studies covering several fields of demography, which should rightly be listed in two or more divisions, are included in only one division, i.e. in the division representing the primary field, on which the report is centered.

Lists of literature on population research have been published in Yearbooks II-IV of the Family Federation of Finland and since 1960 in the Yearbook of Population Research in Finland.

\section{A. GENERAL POPULATION STUDIES AND THEORIES}

Norio, Reijo. Mistä me olemme kotoisin? [ Where do we come from?]. Käytännön Lääkäri, Vol. 44, No. 1, 2001, 33-36 pp.

Pitkänen, Kari (ed.). Artikkeleita Suomen väestöntutkimuksesta: väestötieteen johdantokurssiin liittyva moniste [Articles on Finnish population reserarch: a collection used in the introductory course of population studies]. Helsingin yliopiston sosiologian laitoksen monisteita, No. 62. 2002. 305 pp. Helsingin yliopisto, sosiologian laitos, Helsinki. ISBN 951-45-8265-9.

Westerholm, John. Populating Finland. Fennia: International Journal of Geography, Vol. 180 , No. 1-2, 2002, 123-140 pp. 


\section{B. REGIONAL POPULATION STUDIES}

Mathur, Ajeet. Are Finland's local communities sustainable without internationalisation? Series A 3, Working papers, No. 35, University of Tampere, School of Business Administration. 2001. 24 pp. University of Tampere, Tampere. ISBN 951-44-5161-9.

Sisäasiainministeriö [Ministry of the Interior]. Alueiden tulevaisuuden haasteet: osaaminen, yhteistyo ja hyvinvointi [The challenges of the regions for the future: know-how, co-operation, and welfare]. Sisäasiainministeriön julkaisu, No. 12/2002. 2002. 138 pp. Sisäasiainministeriö, Helsinki. ISBN 951-734-530-5.

\section{SPATIAL DISTRIBUTION}

Hirvonen, Martti. Suomen väestön keskittyminen suuriin keskuksiin vuodesta 1875 vuoteen 2000 [The concentration of the Finnish population to large centers from 1875 to 2000]. Siirtolaisuus, Vol. 28, No. 4, 2001, 14-17 pp.

Myrskylä, Pekka. Väestö jatkaa keskittymistä samoin työpaikat [The concentration of population goes on as well as the workplaces]. Tulevaisuuden näkymiä, No. 2, 2002, 5-15 pp.

Ritsilä, Jari. Studies on the spatial concentration of human capital. Jyväskylä studies in business and economics, No. 7. 2001. 140, [2] pp. University of Jyväskylä, Jyväskylä. ISBN 951-39-0859-3. Doctoral dissertation.

Vaattovaara, Mari. Future developments of residential differentiation in the Helsinki metropolitan area: are we following the European model? Yearbook of Population Research in Finland, Vol. 38, 2002, 107-123 pp.

\section{TRENDS IN POPULATION GROWTH AND SIZE}

Alho, Juha M. The population of Finland in 2050 and beyond. Keskusteluaiheita, No. 826. 2002. 28 pp. ETLA, Helsinki.

Honkanen, Ossi. Kainuulla ja Uudellamaalla menee lujaa - eri suuntiin [The mobility of the population of Kainuu and Uusimaa regions is fast - to reverse directions]. Hyvinvointikatsaus, No. 4, 2001, 5-10 pp.

Korhonen, Sirpa; Keränen, Sirpa; Keränen, Heino. Kainuun väestöennuste 1999-2020 [Kainuu's population projection 1999-2020]. Julkaisu, B, No. 41. 59 pp. 2002. Kainuun liitto, Kajaani.

Majava, Altti. "Lisääntykää ja täyttäkää maa" Onko väestönkasvu ihmiskunnan kohtalonkysymys? [Be fruitful, multiply, and replenish the earth: is population growth the question of fate of the mankind]. In: Artikkeleita Suomen väestöntutkimuksesta: väestötieteen johdantokurssiin liittyvä moniste. Helsingin yliopiston sosiologian laitoksen monisteita, No. 62. 2002. 24-32 pp. Helsingin yliopisto, sosiologian laitos, Helsinki. ISBN 951-45-8265-9.

Mikkonen, Kauko. Jakobstadsregionen 2030: utvecklingsprognoserna för befolkning och bebyggelsestruktur [Jakobstad area 2030: the forecasts of the population development and settlement structure]. Selvityksiä ja raportteja, No. $85.2001 .40 \mathrm{pp}$. Vaasan yliopisto, Vaasa. ISBN 951-683-954-1.

Mikkonen, Kauko. Pietarsaaren seutu 2030: väestön ja asutusrakenteen kehitysennusteet [Pietarsaari area 2030: the forecasts of the population development and settlement structure]. Selvityksiä ja raportteja, No. 79. 2001. 40 pp. Vaasan yliopisto, Vaasa. ISBN 951-683-933-9.

Myrskylä, Pekka. Yhä oudompia väestörakenteita odotettavissa [Even more strange population structures to be expected]. Hyvinvointikatsaus, No. 4, 2001, 11-17 pp.

Parkkinen, Pekka; Mella, Ilkka. Väestön ja työllisyyden kehitysnäkymiä: Valtioneuvoston 
tulevaisuusselonteko eduskunnalle: oheisjulkaisu [Development trends of population and employment: the report of the Government to the Parliament concerning future: a supplementary publication]. Valtioneuvoston kanslian julkaisusarja, No. 2001/10. 2001. 47 pp. Valtioneuvoston kanslia, Helsinki. ISBN 952-5354-16-4.

Parkkinen, Pekka. Suomen ja muiden unionimaiden väestön ikärakenne vuoteen 2050 [The age structure of Finland and other EU countries until 2050]. Keskustelualoitteita, No. 265. 2002. 25 pp. Valtion taloudellinen tutkimuskeskus, Helsinki. ISBN 951-561-390-6.

Pitkänen, Kari. Maailman väestönkehitys: pitkän ajan kehityslinjat [World's population development: long-term trends]. In: Artikkeleita Suomen väestöntutkimuksesta: väestötieteen johdantokurssiin liittyvä moniste. Helsingin yliopiston sosiologian laitoksen monisteita, No. 62. 2002. 5-23 pp. Helsingin yliopisto, sosiologian laitos, Helsinki. ISBN 951-45-8265-9.

Rantala, Olavi. EU:n itälaajenemisen vaikutus Suomen väestökehitykseen [The impact of EU englargement on population developments in Finland]. Keskusteluaiheita, No. 764. 2001. 15, [3] pp. ETLA, Helsinki. Sum in Fin, Eng.

Rusanen, Jarmo; Muilu, Toivo; Colpaert, Alfred. Lasten määrä vähenee sekä taajamissa että maaseudulla [The number of children diminishes both in localities and in rural areas]. Kuntapuntari, No. 5, 2002, 10-13 pp.

Tuominen, Ville-Mikael. Tampereen väestökasvusta [On the population growth of the city of Tampere]. Tammerkoski: Tampereen seudun kotiseutulehti, No. 8, 2002, 10-13 pp.

Valtioneuvosto [The Finnish Government]. Tasapainoisen kehityksen Suomi 2015: valtioneuvoston tulevaisuusselonteko [Finland 2015 - balanced development: Government report to Parliament on Finland's future prospects]. Valtioneuvoston kanslian julkaisusarja, No. 2001/ 7. $2001.31 \mathrm{pp}$. Valtioneuvoston kanslia, Helsinki. ISBN 952-5354-13-X. Published also in Swedish and English.

\section{E. MORTALITY}

Bobak, M.; Murphy, M.; Pikhart, H.; Martikainen, P.; Rose, R.; Marmot, M. Mortality patterns in the Russian Federation: indirect technique using widowhood data. Bulletin of World Health Organization, Vol. 80, No. 11, 2002, 876-881 pp.

Elo, Irma; Drevenstedt, Greg L. Educational differences in cause-specific mortality in the United States. Yearbook of Population Research in Finland, Vol. 38, 2002, 37-54 pp.

Hammar, N.; Kaprio, J.; Hagström, U.; Alfredsson, L.; Koskenvuo, M.; Hammar, T. Migration and mortality: a 20 year follow up of Finnish twin pairs with migrant co-twins in Sweden. Journal of Epidemiology and Community Health, Vol. 56, No. 5, 2002, 362-366 pp.

Heistaro, S.; Jousilahti, P.; Lahelma, E.; Vartiainen, E.; Puska, P. Self rated health and mortality: a long term prospective study in eastern Finland. Journal of Epidemiology and Community Health, Vol. 55, No. 4, 2001, 227-232 pp.

Joukamaa, M.; Heliövaara, M.; Knekt, P.; Aromaa, A.; Raitasalo, R.; Lehtinen, V. Mental disorders and cause-specific mortality. British Journal of Psychiatry, Vol. 179, 2001, 498$502 \mathrm{pp}$.

Kalland, M.; Pensola, T.; Meriläinen, J.; Sinkkonen, J. Mortality in children registered in the Finnish child welfare registry: population based study. British Medical Journal, Vol. 323, No. $7306,2001,207-208$ pp.

Koivumaa-Honkanen, H.; Honkanen, R.; Viinamäki, H.; Heikkilä, K.; Kaprio, J.; Koskenvuo, M. Life satisfaction and suicide: a 20-year follow-up study. American Journal of Psychiatry, Vol. 158, No. 3, 2001, 433-439 pp.

Lunetta, P.; Penttilä, A.; Sarna, S. The role of alcohol in accident and violent deaths in Finland. Alcoholism, Clinical and Experimental Research, Vol. 25, No. 11, 2001, 1654-61 pp.

Martikainen, P.; Lahelma, E.; Ripatti, S.; Albanes, D.; Virtamo, J. Educational differences in lung cancer mortality in male smokers. International Journal of Epidemiology, Vol. 30, No. 2, 2001, 264-267 pp. 
Martikainen, P.; Mäkelä, P.; Koskinen, S.; Valkonen, T. Income differences in mortality: a register-based follow-up study of three million men and women. International Journal of Epidemiology, Vol. 30, No. 6, 2001, 1397-406 pp.

Martikainen, P.; Valkonen, T.; Martelin, T. Change in male and female life expectancy by social class: decomposition by age and cause of death in Finland 1971-95. Journal of Epidemiology and Community Health, Vol. 55, No. 7, 2001, 494-499 pp.

Martikainen, Pekka; Aromaa, Arpo; Lahelma, Eero; Heliövaara, Markku; Klaukka, Timo; Knekt, Paul; Maatela, Jouni; Reunanen, Antti. Perceived health and cause-specific mortality among Finnish men and women aged 30 and over. Yearbook of Population Research in Finland, Vol. 38, 2002, 25-36 pp.

Menotti, A.; Blackburn, H.; Kromhout, D.; Nissinen, A.; Adachi, H.; Lanti, M. Cardiovascular risk factors as determinants of 25-year all-cause mortality in seven countries study. European Journal of Epidemiology, Vol. 17, No. 4, 2001, 337-46 pp.

Menotti, A.; Mulder, I.; Nissinen, A.; Feskens, E.; Giampaoli, S.; Tervahauta, M.; Kromhout, D. Cardiovascular risk factors and 10-year all-cause mortality in elderly European male populations; the FINE study, Finland, Italy, Netherlands, Elderly. European Heart Journal, Vol. 22, No.7, 2001, 573-579. pp.

Menotti, A.; Mulder, I.; Nissinen, A.; Giampaoli, S.; Feskens, E.J.; Kromhout, D. Prevalence of morbidity in elderly male populations and their impact of 10-year all-cause mortality: The FINE study (Finland, Italy, Netherlands, Elderly). Journal of Clinical Epidemiology, Vol. 54, No. 7, 2001, 680-686 pp.

Mäkelä, P.; Ripatti, S.; Valkonen, T. Alue-erot miesten alkoholikuolleisuudessa [Regional differerences in men's alcohol-related mortality]. Suomen Lääkärilehti, Vol. 56, No. 23, 2001, 2513-19 pp.

Möller, T.R.; Garwicz, S. ; Barlow, L.; Falck, Winther J.; Glattre, E. ; Olafsdottir, G.; Olsen, J.H.; Perfekt, R.; Ritvanen, A.; Sankila, R.; Tulinius, H. Decreasing late mortality among five-year survivors of cancer in childhood and adolescence: a population-based study in the Nordic countries. Journal of Clinical Oncology, Vol. 19, No. 13, 2001, 3173-81 pp.

Notkola, Veijo; Martelin, Tuija; Koskinen, Seppo. Socioeconomic position in childhood and adult cardiovascular mortality in 1971-98 in Finland - register-based follow-up study of a large sample from the 1950 census. Yearbook of Population Research in Finland, Vol. 38, 2002, 13-23 pp.

Nurminen, M.; Karjalainen, A. Epidemiologic estimate of the proportion of fatalities related to occupational factors in Finland. Scandinavian Journal of Work, Environment \& Health, Vol. 27, No. 3, 2001, 161-213 pp.

Ostamo, A.; Lönnqvist, J. Attempted suicide rates and trends during a period of severe economic recession in Helsinki, 1989-1997. Social Psychiatry and Psychiatric Epidemiology, Vol. 36, No. 7, 2001, 354-60 pp.

Ostamo, A. Excess mortality of suicide attempters. Social Psychiatry and Psychiatric Epidemiology, Vol. 36, No. 1, 2001, 29-35 pp.

Pelkonen, M.; Notkola, I.-L.; Tukiainen, H.; Tervahauta, M.; Tuomilehto, J.; Nissinen, A. Smoking cessation, decline in pulmonary function and total mortality: a 30 year follow up study among the Finnish cohorts of the Seven Countries Study. Thorax, Vol. 56, No. 9, 2001, $703-707 \mathrm{pp}$.

Pensola, T.H.; Valkonen, T. Effect of parental social class, own education and social class on mortality among young men. European Journal of Public Health, Vol. 12, No. 1, 2002, 29 $36 \mathrm{pp}$.

Pitkänen, Kari. Myrskyluodon Maijan vaarallinen maailma: hukkumiskuolemat Ahvenanmaalla 1800-1950 [The dangerous world of Maija from Myrskyluoto: drowning deaths at the Aland Archipelago in 1800-1950]. In: Keulakuvia ja peränpitäjiä, edited by Riitta Oittinen and Marjatta Rahikainen. 2000. 79-96 pp. Suomen Historiallinen Seura, Helsinki. ISBN 951-710-125-2.

Pitkänen, Kari. Early mortality decline in Norway in comparative perspective. In: Historical studies in mortality decline, edited by William H. Hubbard et al. 2002. 11-22 pp. Novus, 
Oslo. ISBN 82-7099-360-3.

Pitkänen, Kari. Famine mortality in nineteenth-century Finland: is there a sex bias? In: Famine demography, edited by Tim Dyson and Cormac Ó Gráda. 2002. 65-92 pp. Oxford University Press, Oxford. ISBN 0-19-925-191-6.

Poikolainen, K.; Leppänen, K.; Vuori, E. Alcohol sales and fatal alcohol poisonings: a timeseries analysis. Addiction, Vol. 97, No. 8, 2002, 1037-40 pp.

Pyhälä, Reijo; Tervahauta, Risto; Kleemola, Marjaana; Korpela, Heikki; Ikonen, Niina; Sarjakoski, Matti; Saari, Matti; Rostila, Timo. Influenssa väisti vanhuksia - talvinen ylikuolleisuus romahti [The influenza excluded the elderly - the winter excess mortality collapsed]. Suomen Lääkärilehti, Vol. 56, No. 33, 2001, 3197-01 pp.

Rytkönen, M.; Rusanen, J.; Näyhä, S. Small-area variation in mortality in the city of Oulu, Finland, during the period 1978-1995. Health Place, Vol. 7, No. 2, 2001, 75-79 pp.

Räsänen, P.; Hakko, H.; Jokelainen, J.; Tiihonen, J. Seasonal variation in specific methods of suicide: a national register study of 20,234 Finnish people. Journal of Affective disorders, Vol. 71 , No. 1-3, 2002, 51-59 pp.

Salo, Mikko A.; Alho, Juha M. Farm deaths in North Karelia. Yearbook of Population Research in Finland, Vol. 38, 2002, 145-157 pp.

Salomaa, V.; Miettinen, H.; Niemelä, M.; Ketonen, M.; Mahonen, M.; Immonen-Raiha, P.; Lehto, S.; Vuorenmaa, T.; Koskinen, S.; Palomäki, P.; Mustaniemi, H.; Kaarsalo, E.; Arstila, M.; Torppa, J.; Kuulasmaa, K.; Puska, P.; Pyorala, K.; Tuomilehto, J. Relation of socioeconomic position to the case fatality, prognosis and treatment of myocardial infarction events; the FINMONICA Register study. Journal of Epidemiology and Community Health, Vol. 55, No. 7, 2001, 475-482 pp.

Salomaa, Veikko; Niemelä, Matti; Miettinen, Heikki; Ketonen, Matti; Immonen-Räihä, Pirjo; Koskinen, Seppo; Mähönen, Markku; Lehto, Seppo; Vuorenmaa, Tapio; Palomäki, Pertti; Mustaniemi, Harri; Kaarsalo, Esko; Arstila, Matti; Torppa, Jorma; Kuulasmaa, Kari; Puska, Pekka; Pyörälä, Kalevi; Tuomilehto, Jaakko. Sepelvaltimotautikuolleisuuden, kohtausten ilmaantuvuuden ja kohtausten tappavuuden yhteys sosioekonomiseen asemaan Suomessa vuosina 1983-1992: FINMONICAn infarktirekisteritutkimus [Relation of socioeconomic position to coronary artery disease mortality and incidence and lethality of attacks in Finland in 1983-1992: The FINMONICA MI Study]. Suomen Lääkärilehti, Vol. 56. No. 38, 2001. 3811-817 pp.

Sauvola, A.; Räsänen, P.K.; Joukamaa, M.I.; Jokelainen, J.; Järvelin, M.R.; Isohanni, M.K. Mortality of young adults in relation to single-parent family background: a prospective study of the northern Finland 1966 birth cohort. European Journal of Public Health, Vol. 11, No. 3, 2001, 284-286 pp.

Turpeinen, Oiva. Miksi imeväiskuolleisuuden kausivaihteluissa tavaton suuruus? [What caused huge seasonal fluctuations in infant mortality?]. Hippokrates, Vol. 18, 2001, 124-153 pp. Sum in Eng.

Valkonen, Tapani Trends in differential mortality in European countries. In: Vallin, Jacques; Meslé, France; Valkonen, Tapani. Trends in mortality and differential mortality. Population studies, No. 36. 2001. 185-300 pp. Council of Europe Publishing, Strasbourg. ISBN 92-871-4725-6.

Valkonen, Tapani. Tendances en matière de mortalité et mortalité différentielle en Europe. In: Vallin, J.; Meslé, F.; Valkonen, T. Tendances en matière de mortalité et mortalité différentielle. Etudes démoraphiques, No 36. 2001. 189-310 pp. Conseil de l'Europe, Strasbourg. ISBN 92-871-4724-8.

Valkonen, Tapani. Life expectancy and adult mortality in industrialized countries. In: International Encyclopedia of the Social \& Behavioral Sciences, editors-in-chief Neil J. Smelser and Paul B. Baltes. Vol. 13. 2001. 8822-27 pp. Elsevier, Amsterdam. ISBN 0-08-043076-7.

Valkonen, Tapani. Les inégalités sociales devant la mort [Inequality in front of death]. In: Démographie: analyse et synthèse, No. 3: Les déterminants de la mortalité, edited by Jacques Vallin, Graziella Caselli, and Guillaume Wunsch. 2002. 351-372 pp. Institut national d'etudes démographiques, Paris. ISBN 2-7332-2013-6. 
Valkonen, Tapani; Kauppinen, Timo. M. Miesten kuolleisuuden alue-erot ja sosiaalinen segregaatio pääkaupunkiseudulla $=$ social segregation och lokala skillnader $\mathrm{i}$ dödlighet bland män $\mathrm{i}$ Huvudstadsregionen [The geographical differences in male mortality and social segregation in the Helsinki metropolitan area]. Kvartti, No. 1, 2001, 7-21 pp. In Fin, Swe.

Valkonen, Tapani; Kauppinen, Timo M. Male mortality in the Helsinki metropolitan area. Quarterly [Kvartti], No. 3, 2001, 24-28 pp.

Vuori, Erkki; Poikolainen, Kari; Kontula, Osmo; Virtanen, Ari. Suomalainen huumekuolema 1990-1996 [Finnish death of drugs 1990-1996]. Suomen Lääkärilehti, Vol. 56, No. 24, 2001, 2635-40 pp.

\section{F. FERTILITY}

Jensen, T.K.; Slama, R.; Suominen, J.; Cawood, E.H.; Andersen, A.G.; Eustache, F.; Irvine, S.; Auger, S.; Jouannet, P.; Vierula, M.; Jörgensen, N.; Toppari, J.; Skakkeback, N.E.; Keiding, N.; Spira, A. Regional differences in waiting time to pregnancy among fertile couples from four European cities. Human Reproduction, Vol. 16, No. 12, 2001, 2697-04 pp.

Meskus, Mianna. Sikönlähdettämisen alakulttuuri 1900-luvun alun Suomessa [The subculture of illegal abortion in Finland in the early $20^{\text {th }}$ century]. Sosiologia, Vol. 38, No. 4, 2001, 287-299 pp.

Paajanen, Pirjo. Perhebarometri 2002: saako haikara tulla käymään? Suomalaisten lastenhankinnan ihanteet ja todellisuus [Family survey 2002: May the stork visit you? The Finns' family size ideals and reality]. Katsauksia E, No. 14. 2002. 103 pp. Väestöliitto, Väestöntutkimuslaitos, Helsinki. ISBN 952-9605-83-8.

Ruokolainen, Anne; Notkola, Irma-Leena. Familial, situational, and attitudinal determinants of third-birth intentions and their uncertainty. Yearbook of Population Research in Finland, Vol. 38, 2002, 179-206 pp.

Säävälä, Minna. Fertility and familial power relations: procreation in South India. Monograph series, Nordic institute of African studies, No. 87. 2001. 239 pp. Curzon, Richmond. ISBN 07007-1484-7.

Säävälä, Minna. Väestö ja hedelmällisyys Etelä-Intiassa [Population and fertility in South-India]. In: Artikkeleita Suomen väestöntutkimuksesta: väestötieteen johdantokurssiin liittyvä moniste. Helsingin yliopiston sosiologian laitoksen monisteita, No. 62. 2002.86-99 pp. Helsingin yliopisto, sosiologian laitos, Helsinki. ISBN 951-45-8265-9.

Vikat, Andres. Fertility in Finland in the 1980s and 1990s: analysis of fertility by age and parity. Yearbook of Population Research in Finland, Vol. 38, 2002, 159-178 pp.

Vikat, A.; Rimpelä, A.; Kosunen, E.; Rimpelä, M. Sociodemographic differences in the occurrence of teenage pregnancies in Finland in 1987-1998: a follow up study. Journal of Epidemiology and Community Health, Vol. 56, No. 9, 2002, 659-68 pp.

Vikat, Andres; Kosunen, Elise; Rimpelä, Matti. Risk of postpartum abortion in Finland: a registerbased study. Perspectives on Sexual and Reproductive Health, Vol. 34, No. 2, 2002, 84-90 pp.

\section{G. NUPTIALITY AND THE FAMILY}

Finnäs, Fjalar. Language and partner selection. In: Nordic demography: trends and differentials, edited by Jørgen Carling. Scandinavian Population Studies, Vol. 13. 2002. 219-230 pp. Unipub Forlag and Nordic Demographic Society, Oslo. ISBN 82-7477-091-9.

Hämynen, Tapio. "Paha pahan kera, pahatta vie pahempi": rajakarjalaisten avioliitot erilaisten kontaktien kuvastajana 1802-1918 [The marriages of the border Karelians describing different contacts in 1802-1918]. In: Ihmisiä, ilmiöitä ja rakenteita historian virrassa: professori Antero Heikkiselle 60-vuotisjuhlapäivänä omistettu juhlakirja, edited by Jukka Korpela, Tapio Hämynen, and Arto Nevala. Studia Carelica Humanistica, No. 16. 2001. 227-344 pp. Joen- 
suun yliopiston humanistinen tiedekunta, Joensuu. ISBN 951-708-973-2.

Jalovaara, Marika. Socio-economic status and divorce in first marriages in Finland 1991-93. Population Studies, Vol. 55, No. 2, 2001, 119-33 pp.

Jalovaara, Marika. Socioeconomic differentials in divorce risk by duration of marriage. Demographic Research $<$ http://www. demographic-research.org $>$ Vol. 7, Article 16 (Published November 29, 2002), 538-564 pp.

Kartovaara, Leena. Grannies and granddads in the spotlight. 2001. 9 pp. In: Papers of the European Population Conference, Helsinki, June 6-9, 2001, edited by Mika Takoja, Mari Pakarinen, and Ismo Söderling. Theme B: Families and Households. 2001. Organizers: EAPS (European Association for Population Studies), Väestöliitto, The Family Federation of Finland, Statistics Finland, and The Finnish Demographic Society. Available at $<$ http://www.vaestoliitto.fi/toimintayksikot/vaestontutkimuslaitos/eapskonferenssi/papers.html $>$. ISBN 952-9605-76-5 (PDF).

Kartovaara, Leena. Perhe on paras: väestötilastollinen tutkimusretki suurten ikäluokkien perheisiin [Family is best: a vital statistical expedition to the families of the baby-boom generation]. Hyvinvointikatsaus, No. 1, 2002, 8-14 pp.

Katajala, Kimmo. "Sinun kanssasi ei ole koskaan hyvâ": avioerot Käkisalmen läänissä 1600luvulla [It is never nice with you": divorces in the Käkisalmi province in the 17th century. In: Ihmisiä, ilmiöitä ja rakenteita historian virrassa: professori Antero Heikkiselle 60-vuotisjuhlapäivänä omistettu juhlakirja, edited by Jukka Korpela, Tapio Hämynen, and Arto Nevala. Studia Carelica Humanistica, No. 16. 2001. 111-126 pp. Joensuun yliopiston humanistinen tiedekunta, Joensuu. ISBN 951-708-973-2.

Katajala-Peltomaa, Sari; Vuolanto, Ville. Tulkinnan kerrokset - tutkimuskohteena antiikin ja keskiajan perhe [The layers of interpretation - the family of antiquity and Middle Ages as an object of research]. In: Historioitsijan arki \& tutkimuksen prosessi, edited by Sari Autio, Sari Katajala-Peltomaa, and Ville Vuolanto. 2001. 29-47 pp. Vastapaino, Tampere. ISBN 951-768-094-5.

Moring, Beatrice. Familjestrategier i det förindustriella Finland: demografi, ekonomi, ekologi och hushåll [Family strategies in the preindustrial Finland: demography, economy, ecology and households. In: Keulakuvia ja peränpitäjiä, edited by Riitta Oittinen and Marjatta Rahikainen. 2000. 117-134 pp. Suomen Historiallinen Seura, Helsinki. ISBN 951-710-125-2.

Moring, Beatrice. Age at marriage and the life course in pre-industrial Finland: socio-economic and regional differences. In: Nordic demography in history and present-day society, edited by Lars-Göran Tedebrand and Peter Sköld. Scandinavian Population Studies, Vol. 12 and Report No. 18 from the Demographic Data Base, Umeå University. 2001. 121-141 pp. Umeå University, Umeå. ISBN 91-7305-203-5.

Moring, Beatrice. Widowhood options and strategies in preindustrial Northern Europe: socioeconomic differences in household position of the widowed in 18th and 19th century Finland. History of the Family, Vol. 7, No. 1, 2002, 79-99 pp.

O'Leary, Richard; Finnäs, Fjalar. Education, social integration and minority-majority group intermarriage. Sociology, Vol. 36, No. 2, 2002, 235-254 pp.

Pöllä, Matti. Vienankarjalainen perhelaitos 1600-1900 [The family system of Russian Karelia in 1600-1900]. Suomalaisen Kirjallisuuden Seuran toimituksia, No. 805. 2001. 661 pp. Suomalaisen Kirjallisuuden Seura, Helsinki. ISBN 951-746-242-5.

Räisänen, Tarja. Leskenelämää Valkealassa 1800-luvun puolivälissä [The life of a widow in Valkeala in the 1750s]. In: Keulakuvia ja peränpitäjiä, edited by Riitta Oittinen and Marjatta Rahikainen. 2000. 135-146 pp. Suomen Historiallinen Seura, Helsinki. ISBN 951-710-125-2.

Sauli, Hannele; Kainulainen, Sakari. Yhteiskunnan muutos ja lapsiperheet [The change in society and families with children]. In: Lapsuuden hyvinvointi, edited by Maritta Törrönen. 2001. 42-57 pp. Pelastakaa Lapset ry, Helsinki. ISBN 951-96609-9-2.

Sauvola, Anu. The association between single-parent family background and physical morbidity, mortality, and criminal behaviour in adulthood. Acta Universitatis Ouluensis, Series D, Medica, No. 629. 2001. 72, [32] pp. Oulun yliopisto, Oulu. ISBN 951-42-5940-8 and 95142-5941-6 (PDF), available at $<$ http://herkules.oulu.fi/isbn9514259416/ $>$, accessed on April 3, 2003. Doctoral dissertation. 
Sauvola, A.; Koskinen, O.; Jokelainen, J.; Hakko, H.; Järvelin, M.R.; Räsänen, P. Family type and criminal behaviour of male offspring: the Northern Finland 1966 Birth Cohort Study. International Journal of Psychiatry, Vol. 48, No. 2, 2002, 115-121 pp.

\section{H. MIGRATION}

\section{International migration}

Alitolppa-Niitamo, Anne. Somalis in Finland: the process of integration. In: Variations of the theme Somaliness: proceedings of the EASS/SSLA International Congress of Somali Studies, Turku, Finland, August 6-9, 1998, edited by Muddle Suzanne Lilius. 2001. 41-44 pp. Åbo Akademi University, Centre for Continuing Education, Åbo. ISBN 952-120823-6.

Anttonen, Marjut. Some features of Slovene research on emigration. Siirtolaisuus, Vol. 28, No. 2, 2001, 25-27 pp.

Beijbom, Ulf. Nya Sverige - inte minst en historia om finländare [The New Sweden - not the least a history of Finns]. In: "Once a jolly swagman...": essays on migration in honour of Olavi Koivukangas on his $60^{\text {th }}$ birthday. 2001. 50-67 pp. Institute of Migration, Turku. ISBN 951-9266-74-7.

Enckell, Maria Jarlsdotter. The Finnish migration to and from Russain Alaska and the Pacific Siberian rim 1800-1900. Siirtolaisuus, Vol. 29, No. 4, 2002, 16-22 pp.

Forsander, Annika. Etnisten ryhmien kohtaaminen [The encounter of ethnic groups]. In: Monietnisyys ja työ. Oppimateriaaleja, No. 90. 2001. 31-56 pp. Palmenia-kustannus, Helsinki. ISBN 951-45-8777-4.

Hallenberg, Tanja. Uskonnosta ja maastamuutosta [On religion and emigration]. Siirtolaisuus, Vol. 29, No. 3, 2002, 16-20 pp.

Heikkilä, Elli. Migration and the future challenges in an integrated Europe. In: "Once a jolly swagman...": essays on migration in honour of Olavi Koivukangas on his $60^{\text {th }}$ birthday. 2001. 81-89 pp. Institute of Migration, Turku. ISBN 951-9266-74-7.

Hjerppe, Reino. EU:n laajeneminen ja muuttoliikepaineet [The enlargement of the EU and the pressure on migration]. In: Muuttolikkeet vuosituhannen vaihtuessa - halutaanko niitä ohjata? Muuttoliikesymposium 2000, Turku 22.-24.11., edited by Elli Heikkilä. Siirtolaisuustutkimuksia A, No. 24. 2001. 137-143 pp. Siirtolaisuusinstituutti, Turku.

ISBN 951-9266-73-9.

Karni, Michael G. Torn loyalties: Finnish immigrants in America and the Civil War in Finland. In: "Once a jolly swagman...": essays on migration in honour of Olavi Koivukangas on his $60^{\text {th }}$ birthday. 2001. 90-96 pp. Institute of Migration, Turku. ISBN 951-9266-74-7.

Kirkas, Tiina (ed.). Eurooppa ja ihmissalakuljetus [Europe and trafficking of people]. 2002. 95, [2] pp. Suomen Pakolaisapu, Helsinki. ISBN 952-91-4489-X.

Kivisto, Peter. Post-colonial Britain: immigration and the emergence of a multicultural society. Siirtolaisuus, Vol. 28, No. 4, 2001, 3-13 pp.

Korkalainen, Sari. Reintegration of returning workers: a case study from the Philippines. Turun yliopiston maantieteen laitoksen monisteita, No. 24. 2002.77 pp. Turun yliopisto, Turku. ISBN 951-29-2287-8.

Korkiasaari, Jouni. Suomalaisten Ruotsiin suuntautuneen siirtolaisuuden yhteiskunnalliset syyt 1900-luvulla [The social reasons of the 20th century Finnish migration to Sweden]. In: "Once a jolly swagman...": essays on migration in honour of Olavi Koivukangas on his $60^{\text {th }}$ birthday. 2001. 97-117 pp. Institute of Migration, Turku. ISBN 951-9266-74-7.

Korkiasaari, Jouni. Suomalaiset Ruotsissa II maailmansodan jälkeen [The Finns in Sweden after the Second World War]. Siirtolaisuus, Vol. 28, No. 1, 2001, 13-19 pp.

Kostiainen, Auvo. Historian näkökulmat kohtaavat - liikkuvuuden historian tutkimus [The views of history meet - the research of the history of mobility]. In: Historioitsijan arki \& tutkimuksen prosessi, edited by Sari Autio, Sari Katajala-Peltomaa, and Ville Vuolanto. 
2001. 69-83 pp. Vastapaino, Tampere. ISBN 951-768-094-5.

Kultalahti, Olli. Kansallisia ja kansainvälisiä muuttopaineita uuden vuosituhannen kynnyksellä [National and international migration pressures at the dawn of the new millennium]. In: Muuttoliikkeet vuosituhannen vaihtuessa - halutaanko niitä ohjata? Muuttolikesymposium 2000, Turku 22.-24.11., edited by Elli Heikkilä. Siirtolaisuustutkimuksia A, No. 24. 2001. 71-89 pp. Siirtolaisuusinstituutti, Turku. ISBN 951-9266-73-9.

Lahti-Argutina, Eila. Olimme joukko vieras vaan: venäjänsuomalaiset vainonuhrit Neuvostolittossa 1930-luvun alusta 1950-luvun alkuun [We were merely a group of strangers: the persecuted Russia's Finns in the Soviet Union from the beginning of the 1930s to the beginning of the 1950s. 2001.651 pp. Siirtolaisuusinstituutti, Turku. ISBN 951-9266-72-0.

Lankinen, Markku. Vaivaako aivovuoto? [Are we being brain-drained?]. Tutkimuksia, No. 5. 2002. 45, 1 pp. Helsingin kaupungin tietokeskus, Helsinki. ISBN 951-718-954-0. Sum in Swe, Eng.

Lehti, Martti. Naiskauppa, laiton siirtolaisuus ja Suomi: nykytilanne, lainsäädäntöja tutkimuslähteet [Trafficking in women, illegal migration, and Finland]. Oikeuspoliittisen tutkimuslaitoksen julkaisuja, No. 186. 2002. 103 pp. Oikeuspoliittinen tutkimuslaitos, Helsinki. ISBN 951-704-273-6.

Majava, Altti. Nykyajan kansainvaellukset: siirtolaisuuden ja pakolaisuuden yleismaailmalliset näkymät [Migration of today: the global views of migration and exile]. In: Artikkeleita Suomen väestöntutkimuksesta: väestötieteen johdantokurssiin liittyvä moniste. Helsingin yliopiston sosiologian laitoksen monisteita, No.62. 2002. 220-231 pp. Helsingin yliopisto, sosiologian laitos, Helsinki. ISBN 951-45-8265-9.

Mattila, Heikki S. Search for new immigration policy in Western Europe. 2001. 20 pp. In: Papers of the European Population Conference, Helsinki, June 6-9, 2001, edited by Mika Takoja, Mari Pakarinen, and Ismo Söderling. Theme E: International Migration and Migrant Populations. Organizers: EAPS (European Association for Population Studies), Väestöliitto, The Family Federation of Finland, Statistics Finland, and The Finnish Demographic Society. Available at

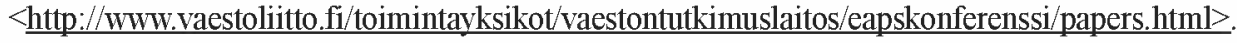
ISBN 952-9605-76-5 (PDF).

Nevalainen, Pekka. Vienasta Suomeen ja takaisin: Itä-Karjalan pakolaisten vaelluksia vuosina 1918-1929 [From Russian Karelia and back: migrations of the refugees of Eastern Karelia in 1918-1929]. In: Ihmisiä, ilmiöitä ja rakenteita historian virrassa: professori Antero Heikkiselle 60-vuotisjuhlapäivänä omistettu juhlakirja, edited by Jukka Korpela, Tapio Hämynen, and Arto Nevala. Studia Carelica Humanistica, No. 16. 2001. 257-267 pp. Joensuun yliopiston humanistinen tiedekunta, Joensuu. ISBN 951-708-973-2.

Nevalainen, Pekka. Punaisen myrskyn suomalaiset: suomalaisten paot ja paluumuutot idästä 1917-1939 [The Finns of the red storm: the flights and return migrations of the Finns in 1917-1939]. Suomalaisen Kirjallisuuden Seuran toimituksia No. 867. 2002. 402 pp. Suomalaisen Kirjallisuuden Seura, Helsinki. ISBN 951-746-269-7.

Parkkinen, Pekka. Sodan jälkeen Suomessa syntyneet ja uussuomalaiset [The people born in Finland after the Second World War and the newcomer Finns]. Yhteiskuntapolitiikka, Vol. 66, No. 3, 2001, 241-247 pp.

Persson, Lars Olof; Neubauer, Jörg. East-to-West migration and labour market integration in the Baltic Sea region - history, current trends and potential. Sirtolaisuus, Vol. 28, No. 3, 2001, 3-14 pp.

Ryymin, Teemu. "Norjalainen vaara": Norjan kveenipolitiikka Suomen näkökulmasta [The Norwegian danger: Norway's policy concerning people of Finnish origin in Northern Norway]. Historiallinen aikakauskirja, Vol. 99, No. 3, 2001, 252-261 pp.

Salminen, Heikki. Lapsipakolaisuus 1900-luvulla ja suomalaiset sotalapset [Child exile in the 20 th century and Finnish war refugees]. In: "Once a jolly swagman ... ": essays on migration in honour of Olavi Koivukangas on his $60^{\text {th }}$ birthday. 2001. 175-186 pp. Institute of Migration, Turku. ISBN 951-9266-74-7. 
Siikala, Jukka (ed.). Departures: how societies distribute their people. Transactions of the Finnish Anthropological Society, No. 46. 2001. 235, [4] pp. Finnish Anthropological Society, Helsinki. ISBN 952-9573-24-3.

Snellman, Hanna. Ruottiin lähössä! Pohjoissuomalaisten muuttoliike Etelä-Ruotsiin 1960-1970luvuilla [Off to Sweden! Migration from northern Finland to southern Sweden in the 1960s and the 1970s]. Historiallinen Aikakauskirja, Vol. 99, No. 3, 2001, 293-299 pp.

Söderling, Ismo. 'The Finnish attitudes towards immigration and immigrants' - surveys in the Finnish migration research context. In: Demographic and cultural specificity and integration of migrants: $1^{\text {st }}$ workshop organized by the Federal Institute for Population Research in cooperation with the Network for Integrated European Population Studies (NIEPS), 10-11 November 2000, Bingen, Germany. Heft 103. 2001. 119-136 pp. BiB Bundesinstitut für Bevölkerungsforschung, Wiesbaden.

Söderling, Ismo. Die finnischen Einstellungen gegenüber der Zuwanderung und den Migranten - Ergebungen im Kontext der finnischen Migrationsforschung [The Finnish attitudes towards immigration and immigrants - surveys in the Finnish migration research context]. Zeitschrift für Bevölkerungswissenschaft, Vol. 26, 3-4, 2001, 399-411 pp. Summaries in Eng, Fre.

Söderling, Ismo. Siirtolaisuus väestöllisenä resurssina - Suomi eurooppalaisessa kontekstissa [Migration as a population resource - Finland in the European context]. In: "Once a jolly swagman..." ": essays on migration in honour of Olavi Koivukangas on his $60^{\text {th }}$ birthday. 2001. 187-209 pp. Institute of Migration, Turku. ISBN 951-9266-74-7.

Söderling, Ismo. Läntinen Eurooppa ja siirtolaisuus väestöllisenä kysymyksenä [Western Europe and migration as a population issue]. Maailmanpyörä, No. 3, 2002, 4-7 pp.

Söderling, Ismo. Muuttoliike väestöllisena ilmiönä [Migration as a demographic phenomenon]. In: Artikkeleita Suomen väestöntutkimuksesta: väestötieteen johdantokurssiin liittyvä moniste. Helsingin yliopiston sosiologian laitoksen monisteita, No. 62. 2002. 193-219 pp. Helsingin yliopisto, sosiologian laitos, Helsinki. ISBN 951-45-8265-9.

Turpeinen, Oiva. Lännenlokarit: Kainuusta Amerikkaan [The loggers of the West: emigrants from Kainuu to the United States]. Julkaisuja No. 43. 2002. 105 pp. Kainuun liitto, Kajaani. ISBN 952-5326-11-X.

Työministeriö [Ministry of Labour]. EU:n itälaajenemisen vaikutukset työvoiman liikkuvuuteen [The enlargement of the EU and its impacts on the mobility of labor]. Työhallinnon julkaisu, No. 291. 2001. 55, 55, [19] pp. Työministeriö, Helsinki. ISBN 951-735-662-5.

Vesterinen, Pentti. Maahanmuutto: ikääntymisongelmiemme ratkaisu? [Immigration: a solution to our aging problems? Keskustelualoitteita, No. 69. 2002. 15, [4] pp. Helsinki, Valtiovarainministeriö, kansantalousosasto. ISBN 951-804-304-3.

Wester, Holger. Ruotsi ja Amerikka Pohjanmaan muuttokohteina [Sweden and America as destinations of emigration from Ostrobothnia]. In: Härkönen, Hanna (ed.). Tuhat vuotta Pohjanmaan historiaa: Sanomalehtiyliopisto 1999. Julkaisu, No. 20. 2001. 48-53 pp. Vaasan yliopisto, Levón-instituutti, Vaasa. ISBN 951-683-907-X

Vilmusenaho, Risto. Siikajokilaakson siirtolaisuus vuosina 1850-1914: talous- ja sosiaalihistoriallinen tutkimus Kestilän, Paavolan, Piippolan, Pulkkilan, Pyhännän, Rantsilan, Revonlahden ja Siikajoen maastamuutosta [The emigration from the Siikajoki region in 18501914: economic and social historical study on the emigration of Kestilä, Paavola, Piippola, Pulkkila, Pyhäntä, Rantsila, Revonlahti, and Siikajoki]. R. Vilmusenaho, Haapavesi. 2001. [14], 445 pp. + [17] folded sheets. Doctoral dissertation. Sum in Eng.

Ylänkö, Maaria. La Finlande, pays d'accueil: approche historique et anthropologique: le cas des immigrés d'Afrique noire [Finland, the country of reception: a historical and anthropological approach: the case of immigrants from Sub-Saharan Africa]. Commentationes Scientiarum Socialium, No. 60. 2002. 294, [6] pp. Suomen tiedeseura, Helsinki. ISBN 951-653-314-0. Doctoral dissertation.

Ylänkö, Maaria. The two faces of globalization - migration and the globalization of cultures. In: Immigration and Economy in the globalization process, edited by Annika Forsander. Sitra report series 20. 2002. 10-47 pp. SITRA, Helsinki. ISBN 951-563-415-6. 


\section{Internal migration}

Böckerman, Petri; Hämäläinen, Kari; Maliranta, Mika. Explaining regional job and worker flows. Working papers, W, No. 304. 2002. 35 pp. Helsinki School of Economics, Helsinki. ISBN 951-791-662-0.

Böckerman, Petri; Hämäläinen, Kari; Maliranta, Mika. Sources of job and worker flows: evidence from a panel of regions. Työpapereita, No. 178. 2002. 24 pp. Palkansaajien tutkimuslaitos, Helsinki. ISBN 952-5071-65-0.

Haapanen, Mika; Ritsilä, Jari. Can migration decisions be affected by income taxation policies. Working paper, University of Jyväskylä, School of Business and Economics, No. 238. 2001. 24, [3] pp. University of Jyväskylä, Jyväskylä. ISBN 951-39-1007-5.

Haapanen, Mika. Labour migration and wages. Reports from the School of Business and Economics, No. 29. 2002. 82, [6] pp. Jyväskylä, Jyväskylän yliopisto, taloustieteiden tiedekunta. ISBN 951-39-1176-4. Licentiate thesis.

Heikkilä, Elli. Migrating back to history? The settlement structure and migration in Finland, a 400 years perspective. Nordia geographical publications, Vol. 31, No. 1, 55-67 pp.

Hunnakko, Pekka; Palm, Jarmo. Suurten ikäluokkien eläkeläisten maallemuuttopotentiaali [The potential of the pensioners of the baby-boom generation to move to rural areas]. Julkaisuja, Vaasan yliopisto, Levón-instituutti, No. 100. 2002. 96 pp. Vaasan yliopisto, Vaasa. ISBN 951-683-946-0.

Jutikkala, Eino. Maassamuutto kautta aikojen [Internal migration through ages]. In: Muuttoliikkeet vuosituhannen vaihtuessa - halutaanko nittä ohjata? Muuttoliikesymposium 2000, Turku 22.-24.11., edited by Elli Heikkilä. Siirtolaisuustutkimuksia A, No. 24. 2001. 26-37 pp. Siirtolaisuusinstituutti, Turku. ISBN 951-9266-73-9.

Kainulainen, Sakari. Hyvinvoinnin lisääminen muuttojen yleisin syy [To increase welfare is the most common reason for internal migration]. Kuntapuntari, No. 5, 2002, 26-29 pp.

Kallio, Olavi. Muuttolike ja sen taloudelliset vaikutukset Kuntasuomi 2004 -kunnissa [International migration and its economic effects on the Kuntasuomi 2004 -municipalities]. Suunnittelusarja, Tampereen yliopisto, kunnallistieteiden laitos, No. 52 and KuntaSuomi 2004 -tutkimuksia, No. 30. 2001. 37, [5] pp. Tampereen yliopisto, Tampere. ISBN 95144-5117-1.

Kallio, Olavi; Meklin, Pentti; Siitonen, Pentti; Martikainen, Jukka-Pekka. Muuttoliike ja kuntatalous [Migration and municipal economy]. 2001. 94 pp. Suomen kuntaliitto, Helsinki. ISBN 951-755-541-5.

Kataja, Jukka-Pekka; Volk, Raija. Talouskasvun hiipuminen hidastanut maaltamuuttoa [The decrease of economic growth has decreased the outmigration from rural areas]. Talous \& Yhteiskunta, Vol. 30, No. 4, 2002, 22-26 pp.

Kauppinen, Jarkko. Maassamuuton kuvaaminen koordinaattipohjaisten paikkatietojen perusteella [The description of internal migration on the basis of Geographic Information Systems (GIS)]. In: Muuttoliikkeet vuosituhannen vaihtuessa-halutaanko niitä ohjata? Muuttolikesymposium 2000, Turku 22.-24.11., edited by Elli Heikkilä. Siirtolaisuustutkimuksia A, No. 24. 2001.108-116 pp. Siirtolaisuusinstituutti, Turku. ISBN 951-9266-73-9.

Kauppinen, Jarkko. Ekologinen harha muuttoliikkeen tarkastelussa [Ecologic bias in the investigation of migration]. In: Muuttoliikkeet vuosituhannen vaihtuessa-halutaanko nittä ohjata? Muuttolikesymposium 2000, Turku 22.-24.11., edited by Elli Heikkilä. Siirtolaisuustutkimuksia A, No. 24. 2001. 215-217 pp. Siirtolaisuusinstituutti, Turku. ISBN 951-9266-73-9.

Konttajärvi, Tiina. Työssäkäyntiliikenne, etätyö ja muuttoliike uudella vuosituhannella [Commuting, telework, and migration in the new millennium]. In: Muuttoliikkeet vuosituhannen vaihtuessa - halutaanko niitä ohjata? Muuttoliikesymposium 2000, Turku 22.-24.11., edited by Elli Heikkilä. Siirtolaisuustutkimuksia A, No. 24. 2001. 203-209 pp. Siirtolaisuusinstituutti, Turku. ISBN 951-9266-73-9.

Kultalahti, Olli. Internal migration and spesialising labour markets in Finland. Yearbook of Population Research in Finland, Vol. 37, 2001, 103-125 pp. 
Laakso, Seppo. Kasautuminen Helsingin seudulle - etuja ja ongelmia [The conglomeration to the Helsinki region - advantages or problems]. Talous \& Yhteiskunta, Vol. 30, No. 4, 2002, 7-12 pp.

Lankinen, Markku. Muuttoliike ja kunnan talous [Migration and the municipal economy]. Tutkimuksia, No. 3, 2002. 2002. 68 pp. Helsingin kaupungin tietokeskus, Helsinki. ISBN 951-718-919-2.

[Lintunen, Petri]. Muuttolikkeen vaikutus Espoon väestörakenteeseen vuosina 1997 ja 1999 [The influence of mobility on the population structure of Espoo in 1997 and 1999]. Raportteja Espoosta, No. 7. 2002. 50 pp. Espoon kaupungin keskushallinto, Palvelukeskus, Tietoja tutkimuspalvelujen yksikkö, Espoo.

Luukko, Juha. Muuttoliikkeen syyt ja teoriat: Päijät-Hämeen tapaustutkimus [The reasons and theories of migration: the case of Päijät-Häme region]. The Research Series of the Institute for Regional Economics and Business Strategy, No. 2. 2001. 76 pp. Helsinki University of Technology, Lahti Center, Lahti. ISBN 951-22-5563-4.

Myrskylä, Pekka. Suuret ikäluokat liikkeessä [The baby boomers on the move]. Hyvinvointikatsaus, No. 1, 2002, 2-7 pp.

Nieminen, Mauri. Maassamuuton kehityslinjat nyt ja tulevaisuudessa [The development of internal migration now and in the future. In: Muuttoliikkeet vuosituhannen vaihtuessahalutaanko niitä ohjata? Muuttoliikesymposium 2000, Turku 22.-24.11., edited by Elli Heikkilä. Siirtolaisuustutkimuksia A, No. 24. 2001. 38-46 pp. Siirtolaisuusinstituutti, Turku. ISBN 951-9266-73-9.

Nivalainen, Satu. Maallemuuttajat-millaisia he ovat? [The ones who move to the rural areas - what are they like?] Pellervon taloudellisen tutkimuslaitoksen työpapereita, No. 59. 2002. $44 \mathrm{pp}$. Pellervon taloudellinen tutkimuslaitos, Helsinki. ISBN 952-5299-61-9.

Ovaska, Esko. Saaristoon muutto elämänpolitiikkanaja sosiaaliset verkostot saaristokunnassa [Moving to the archipelago as life policy and social networks in a municipality in the archipelago]. Turun ammattikorkeakoulun tutkimuksia, No. 1.2001. $215 \mathrm{pp}$. Turun ammattikorkeakoulu, Turku. ISBN 952-5113-09-4. Licentiate thesis.

Pehkonen, Aini. Sosiaalisen pääoman merkitys muuttoliiketutkimuksessa [The meaning of social capital in migration research]. In: Muuttoliikkeet vuosituhannen vaihtuessa - halutaanko niitä ohjata? Muuttoliikesymposium 2000, Turku 22.-24.11., edited by Elli Heikkilä. Siirtolaisuustutkimuksia A, No. 24. 2001.290-293 pp. Siirtolaisuusinstituutti, Turku. ISBN 951-9266-73-9.

Ritsilä, Jari. Studies on the spatial concentration of human capital. Jyväskylä studies in business and economics, No. 7. 2001. 140 pp. Jyväskylän yliopisto, Jyväskylä. ISBN 95139-0859-3. Doctoral dissertation.

Saari, Matti. Väestökehitys seutukunnittain vuonna 2000: muutto vie tulevaakin sukupolvea taantuma-alueilta [Population development by sub-regional units in 2000: migration will also take some of the future population from the regions with diminishing economy]. Tietoaika, No. 7, 2001, 10-13 pp.

Söderling, Ismo. Aluerakenne ja väestö muuttoliikkeen kannalta - voidaanko alueellista keskittymistä tukemalla estää alueiden syrjäytyminen? [Regional structure and population from the view of migration - is it possible to prevent the marginalization of regions by supporting regional concentration?]. In: Muuttolikkeet vuosituhannen vaihtuessa-halutaanko niitä ohjata? Muuttolitkesymposium 2000, Turku 22.-24.11., edited by Elli Heikkilä. Siirtolaisuustutkimuksia A, No. 24. 2001. 155-158 pp. Siirtolaisuusinstituutti, Turku. ISBN 951-9266-73-9.

Tervo, Hannu. Does the compositional effect explain the association between rates of inmigration. 2001. 24, [4] pp. Working paper, University of Jyväskylä, School of Business and Economics, No. 239. University of Jyväskylä, Jyväskylä. ISBN 951-39-1026-1.

Tervo, Hannu. Muuttoliike Keski-Suomen kannalta 1990-luvulla [Internal migration considering central Finland in the 1990s]. Julkaisu, Jyväskylän yliopisto, taloustieteen tiedekunta, tutkimuskeskus, No. 150. 2001. 34, [6] s. Jyväskylän yliopisto, Jyväskylä. ISBN 951-39-0900-X.

Tervo, Hannu. Työvoiman liikkuvuus aluetalouksien näkulmasta Suomessa [The mobility of labor from the view of regional economies in Finland]. In: Muuttoliikkeet vuosituhannen 
vaihtuessa-halutaanko niitä ohjata? Munttoliikesymposium 2000, Turku 22.-24.11., edited by Elli Heikkilä. Siirtolaisuustutkimuksia A, No. 24. 2001. 101-107 pp. Siirtolaisuusinstituutti, Turku. ISBN 951-9266-73-9.

Tervo, Hannu. Muuttoliike ei ratkaise työttömyysongelmaa [Migration does not solve the unemployment problem]. Talous \& yhteiskunta, Vol. 30, No. 4, 2002, 26-30 pp.

Tohmo, Timo; Ritsilä, Jari; Nenonen, Tuomo; Haapanen, Mika. Jarrua muuttoliikkeelle [Slow down the migration]. Kunnallisalan kehittämissäätiön tutkimusjulkaisut, No. 31.2001. 92 pp. Kunnallisalan kehittämissäätiö, Helsinki. ISBN 952-9740-86-7.

Vihriälä, Vesa. Maassamuutto ja sihen vaikuttaminen [Internal migration and influencing it]. In: Muuttoliikkeet vuosituhannen vaihtuessa - halutaanko niitä ohjata? Muuttoliikesymposium 2000, Turku 22.-24.11., edited by Elli Heikkilä. Siirtolaisuustutkimuksia A, No. 24. 2001. 152-154 pp. Siirtolaisuusinstituutti, Turku. ISBN 951-9266-73-9.

Väänänen, Maarit. Paluumuutto kotiseudulle Pohjois-Karjalaan [Return migration to the native place to North-Karelia]. Siirtolaisuus, Vol. 28, No. 3, 2001, 15-19 pp,

\section{HISTORICAL DEMOGRAPHY AND DEMOGRAPHIC HISTORY}

Turpeinen, Oiva. Suomen väestö 1638-1815 sekä vertailu Viroon [Finland's population in 1638-1815 and its comparison with Estonia]. In: Ihmisiä, ilmiöitä ja rakenteita historian virrassa: professori Antero Heikkiselle 60-vuotisjuhlapäivänä omistettu juhlakirja, edited by Jukka Korpela, Tapio Hämynen, and Arto Nevala. Studia Carelica Humanistica, No. 16. 2001. 11-48 pp. Joensuun yliopiston humanistinen tiedekunta, Joensuu.

ISBN 951-708-973-2.

\section{J. CHARACTERISTICS}

Alitolppa-Niitamo, Anne. Liminalities: expanding and constraining the options of Somali youth in the Helsinki metropolitian area. Yearbook of Population Research in Finland, Vol. 37, 2001, 126-147 pp.

Anttonen, Marjut. The politization of Kven identities in Northern Norway. In: "Once a jolly swagman...": essays on migration in honour of Olavi Koivukangas on his $60^{\text {th }}$ birthday. 2001. 27-49 pp. Institute of Migration, Turku. ISBN 951-9266-74-7.

Ekholm, Elina. Monietninen yhteiskunta [Multiethnic society]. In: Monietnisyys ja työ. Oppimateriaaleja, No. 90. 2001. 161-188 pp. Palmenia-kustannus, Helsinki. ISBN 951-45-87774.

Finnäs, Fjalar. Finlandssvenskarna inför 2000-talet [The Swedish speaking Finns on the eve of the 21 st century]. Finlandssvensk rapport, No. 40. 2001. 63 pp. Svenska Finlands folkting, Helsingfors. ISBN 952-9700-40-7.

Forsander, Annika; Ekholm, Elina; Nguyen, Cuong Quoc; Alitolppa-Niitamo, Anne; Ali, Abdullahi; Kyntäjä, Eve. Etniset ryhmät Suomessa [Ethnic groups in Finland]. In: Monietnisyys ja työ. Oppimateriaaleja, No. 90. 2001. 83- 160 pp. Palmenia-kustannus, Helsinki. ISBN 951-45-8777-4.

Harviainen, Tapani. The Islamic congregation of Tatars in Finland: acknowledged from 1925 on. Proceedings of the Finnish Institute in the Middle East, No. 3/2001. 2001. 8 pp. Suomen Lähi-Idän instituutin säätiö, Vantaa. ISBN 952-5393-02-X.

Hintikka, Jukka; Koskela, Tarja; Kontula, Osmo; Koskela, Kaj; Koivumaa-Honkanen, HeliTuulie; Viinamäki, Heimo. Religious attendance and life satisfaction in the Finnish general population. Journal of Psychology and Theology, Vol. 29, No. 2, 2001, 158-64 pp.

Honkanen, Ossi. Vuonna 2030 väestöstä joka neljäs on yli 65-vuotias [In 2030 every fourth of the population is over 65 years old]. Kuntapuntari, No. 5, 2001, 3-6 pp. 
Hyyppä, M.T; Mäki, J. Why do Swedish-speaking Finns have longer active life? An area for social capital research. Health Promotion International, Vol. 16, No. 1, 2001, 55-64 pp.

Iskanius, Sanna. Russian-speaking immigrant students in Finland: searching for the meaning of languages and cultures. Siirtolaisuus, Vol. 29, No. 1, 2002, 4-13 pp.

Järvinen, Tero; Vanttaja, Markku. Young people, education and work: trends and changes in Finland in the 1990s. Journal of Youth Studies, Vol. 4, No. 2, 2001, 195-207 pp.

Kannisto, Väinö. Years added to life in old age. Yearbook of Population Research in Finland, Vol. 38, 2002, 97-106 pp.

Kannisto, Väinö. Mode and dispersion of the length of life. Population: An English Selection, Vol. 13, 2001, No. 1, 159-172 pp.

Kauppinen, Timo M. The beginning of immigrant settlement in the Helsinki metropolitan area and the role of social housing. Journal of Housing and the Built Environment, Vol. 17, No. 2, 2002, 173-197 pp.

Laine, Antti. Where East meets West: the last stand of Finns and Karelians in contemporary Karelia? Nationalities Papers, Vol. 29, No. 1, 2001, 53-67 pp.

Mein, G.; Martikainen, P.; Stansfeld, S.A.; Brunner, E.; Furher, R.; Marmot, M. Predictors of early retirement in British Civil Servants. Age and Ageing, Vol. 29, No. 6, 2001, 529-36 pp.

Miettinen, Anneli. Education and the division of household labor in dual-earner families. Yearbook of Population Research in Finland, Vol. 37, 2001, 41-62 pp.

Nivalainen, Satu; Haapanen, Mika. Ikääntyvä ja keskittyvä Suomi: kaupunkien, maaseudun ja vuorovaikutusvalueiden väestökehitys 1975-2030 [Aging and conglomerating Finland: the population development of cities, countryside, and interactive areas in 1975-2030]. Aluekeskus- ja kaupunkipolitiikan yhteistyöryhmän julkaisu, No. 1/02. 2002. 79 pp. + App. Sisäasiainministeriö, Helsinki. ISBN 951-734-540-2.

Rastas, Merja. Maahanmuuttajan asunnottomuus Helsingissä [Homelessness among immigrants in Helsinki]. Suomen ympäristö, No. 582. 2002. 71, [2] pp. Ympäristöministeriö, Helsinki. ISBN 952-11-1242-5.

Roinila, Mika. Finnish ethnicity in the State of Virginia. Siirtolaisuus, Vol. 28, No. 2, 2001, $18-$ $24 \mathrm{pp}$.

Räisänen, Tarja. Solitary old age: women in Finnish agricultural society, 1780-1920. 2001. 6 pp. In: Papers of the European Population Conference, Helsinki, June 6-9, 2001, edited by Mika Takoja, Mari Pakarinen, and Ismo Söderling. Theme L: Looking backward. Organizers: EAPS (European Association for Population Studies), Väestöliitto, The Family Federation of Finland, Statistics Finland, and The Finnish Demographic Society. Available at $<$ http://www.vaestoliitto.fi/toimintayksikot/vaestontutkimuslaitos/eapskonferenssi/papers.html $>$. ISBN 952-9605-76-5 (PDF).

Saarela, Jan; Finnäs, Fjalar. Language-group differences in very early retirement in Finland. Demographic Research $<$ http://www.demographic-research.org $>$ Vol. 7, Article 3 (Published July 31, 2002), 50-66 pp.

Sarvimäki, Anneli; Rajaniemi, Jere. Vanheneminen etnisissä vähemmistöryhmissä [Aging in ethnic minority groups]. Oraita 2/2001. 2001.29 pp. Kuntokallio, Vanhustyön koulutus-ja tutkimuskeskus, Helsinki. ISBN 952-5292-18-5.

Shkolnikov, Vladimir M.; Valkonen, Tapani.; Begun, Alexander.; Andreev, Evgueni M. Measuring inter-group inequalities in length of life. Genus, Vol. 67, No. 3-4, 2001, 33-62 pp.

Söderling, Ismo. Ageing, intergenerational solidarity and age-specific vulnerabilities [Finland]. In: Ageing, intergenerational solidarity, and age-specific vulnerability, Rome, 20-2I A pril, 2001: solicited papers and country reports. Workshop 3. 2001. 357-369 pp. Network for Integrated European Population Studies (NIEPS) and Centrum voor Bevolkings- en Gezinstudie (CBGS), Brussels.

Toivanen, Reetta. Minority rights and minority identities - Sámi in Finland and Sorbs in Germany. Yearbook of Population Research in Finland, Vol. 37, 2001, 83-102 pp.

Ylikarjula, Simo. Pitkäikäisyys tuhat vuotta sitten [Longevity a thousand years ago]. Gerontologia, Vol. 15, No. 4, 2001, 279-278 pp. 


\section{K. DEMOGRAPHIC AND ECONOMIC INTERRELATIONS AND NATURAL RE- SOURCES}

Ahmad, Akhlaq. Yhteisten työmarkkinoiden erottelemia? Maahanmuuttajien työllistymismahdollisuudet suomalaisilla työmarkkinoilla [Segregated by the common labor market? The work possibilities of immigrants in the Finnish labor market]. Sosiologia, Vol. 39, No. 3, 2002, 227-241 pp.

Alho, Kari. Hyödyttääkö vai vahingoittaako maahanmuutto EU:n työvoimaa? [Does immigration benefit or damage the EU labor force]. In: Muuttolikkeet vuosituhannen vaihtuessa - halutaanko niitä ohjata? Muuttoliikesymposium 2000, Turku 22.-24.11., edited by Elli Heikkilä. Siirtolaisuustutkimuksia A, No. 24. 2001. 144-151 pp. Siirtolaisuusinstituutti, Turku. ISBN 951-9266-73-9.

Edvardsson, Ingi Runar; Heikkilä, Elli; Johansson, Mats; Persson, Lars Olof; Stambøl, Lasse Sigbjørn. Competitive capitals: performance of local labour markets - an international comparison based on gross-stream data. In: Muuttoliikkeet vuosituhannen vaihtuessa - halutaanko niitä ohjata? Muuttoliikesymposium 2000, Turku 22.-24.11., edited by Elli Heikkilä. Siirtolaisuustutkimuksia A, No. 24. 2001.47-70 pp. Siirtolaisuusinstituutti, Turku. ISBN 951-9266-73-9.

Forsander, Annika; Ekholm, Elina. Maahanmuuttajat ja työ [Immigrants and work]. In: Monietnisyys ja työ. Oppimateriaaleja, No. 90. 2001. 57-82 pp. Palmenia-kustannus, Helsinki. ISBN 951-45-8777-4.

Forsander, Annika. Immigrants entering Finnish labour market - who is winning, who is losing. In: Demographic and cultural specificity and integration of migrants: $1^{\text {st }}$ workshop organized by the Federal Institute for Population Research in co-operation with the Network for Integrated European Population Studies (NIEPS), 10-11 November 2000, Bingen, Germany. Heft 103. 2001. 137-154 pp. BiB Bundesinstitut für Bevölkerungsforschung, Wiesbaden.

Forsander, Annika. Immigrants in the Finnish labour market - is there ethnic segmentation? In: Muuttoliikkeet vuosituhannen vaihtuessa - halutaanko niitä ohjata? Muuttolikesymposium 2000, Turku 22.-24.11., edited by Elli Heikkilä. Siirtolaisuustutkimuksia A, No. 24. 2001. 240-266 pp. Siirtolaisuusinstituutti, Turku. ISBN 951-9266-73-9.

Forsander, Annika. Kenelle ovet aukeavat? Maahanmuuttajat ja työllistymisen ehdot [Opening the doors? Immigrants and conditions of employment]. Työpoliittinen Aikakauskirja, Vol. 44, No. 2, 2001, 28-38 pp. Sum in Eng.

Forsander, Annika. Maahanmuuttajat ja työllistyminen: Suomi maahanmuuttomaana [Immigrants and employment: Finland as a country of immigration]. In: Maahanmuuttaja kahden kulttuurin välissä = imvandrare mellan två kulturer, 31.10.2000, Säätytalo, Helsinki. 2001. 55-66 pp. Euroopan kulttuurisäätiön Suomen osasto, Helsinki. ISBN 951-8932-15-8.

Forsander, Annika. Migranten auf dem finnischen Arbeitsmarkt - wer sind die Gewinner, wer die Verlierer? [Migrants on the Finnish labour market - who is winning, who is losing?]. Zeitschrift für Bevölkerungswisseschaft, Vol. 26, No. 3-4/2001, 413-431 pp. Summaries in Eng, Fre.

Forsander, Annika. Globalising capital and labor - old structures, new challenges. In: Immigration and Economy in the globalization process, edited by Annika Forsander. Sitra report series 20. 2002. 81-118 pp. SITRA, Helsinki. ISBN 951-563-415-6.

Forsander, Annika. Luottamuksen ehdot: maahanmuuttajat 1990-luvun suomalaisilla työmarkkinoilla [Immigrants in the 1990s Finnish labour market]. Väestöntutkimuslaitoksen julkaisusarja D, No. 39. 2002. 283, [4] pp. Väestöntutkimuslaitos, Väestöliitto, Helsinki. ISBN 952-9605-82-X. Doctoral dissertation.

Forsander, Annika. Maahanmuuttajanaisten marginaalinen asema suomalaisilla työmarkkinoilla [The marginal position of immigrant women in the Finnish labor market]. In: Väkivalta ei tunne kulttuurisia rajoja: maahanmuuttajanaisiin kohdistuva väkivalta Suomessa, edited by Reet Nurmi and Reetta Helander. 2002. 73-80 pp. Sosiaali- ja terveysministeriö and STAKES Sosiaali- ja terveysalan tutkimus- ja kehittämiskeskus. ISBN 951-33-1347-6. 
Forsander, Annika. Maahanmuuttajat suomalaisilla työmarkkinoilla - porstuaan vai peremmälle? [Immigrants in the Finnish labor market - to the porch or farther back]. In: Työelämäkynnykset ja haasteelliset ryhmät työllisyyspolitiikan näkökulmasta. 2002. 16-33 pp. ESRhyvät käytännön julkaisut 8. Työministeriö, Helsinki. ISBN 951-735-595-5.

Forsander, Annika. Työmarkkinoiden kansainvälistymiskehitys Suomessa [The internationalization development of the labor market in Finland]. Yhteiskuntapolitiikka, Vol. 67, No. 3, 2002, 260-268 pp.

Greijus, Sari. Euroopan itälaajenemisen vaikutuksista Suomen työmarkkinoihin: onko odotettavissa muuttoryntäystä Virosta? [The effects of the enlargement of the European Union on the Finnish labor market: will there be a rush of immigrants from Estonia?]. Siirtolaisuus, Vol. 28, No. 4, 2001, 26-33 pp.

Heikkilä, Elli; Korhonen, Sirpa. Supply and demand of labour force in Finland - challenges in terms of achieving "full employment" in all parts of the country. Siirtolaisuus, Vol. 29, No. 2, 2002, 27-31 pp.

Joronen, Tuula. Immigrant entrepreneurship in Finland in the 1990s. In: Immigration and Economy in the globalization process, edited by Annika Forsander. Sitra report series 20. 2002. 119-174 pp. SITRA, Helsinki. ISBN 951-563-415-6.

Kilponen, Juha; Romppanen, Antti. Julkinen talous ja väestön ikääntyminen pitkällä aikavälillä [The public economy and aging of population in the long terms]. Kansantaloudellinen aikakauskirja, Vol. 98, No. 3, 2002, 275-290 pp.

Kinnunen, Helvi. Väestön vanheneminen, työmarkkinat ja julkisen talouden näkymät [The aging of population, labor market, and the outlook for public finances]. Suomen Pankin keskustelualoitteita, No. 28. 2002. 27 pp. Suomen Pankki, Helsinki. ISBN 952-462-019-7. Sum in Fin, Eng.

Kultalahti, Olli. Internal migration and specialising labour markets in Finland. In: "Once a jolly swagman ... ": essays on migration in honour of Olavi Koivukangas on his $60^{\text {th }}$ birthday. 2001. 118-139 pp. Institute of Migration, Turku. ISBN 951-9266-74-7.

Lassila, Jukka; Valkonen, Tarmo. Sosiaalimenot ja väestön ikääntyminen [Social expenditures and population aging]. Etla, Sarja B, No. 187.2002.99 pp. Elinkeinoelämän tutkimuslaitos and Taloustieto, Helsinki. ISBN 951-628-357-8.

Lassila, Jukka; Rantala, Olavi; Valkonen, Tarmo. Varallisuus, verotus ja väestön ikääntyminen [Wealth, taxation, and population aging]. Sosiaali- ja terveysturvan tutkimuksia, No. 70 and Elinkeinoelämän Tutkimuslaitos, Sarja B, No. 194. 2002. 98 pp. Kansaneläkelaitos, Helsinki. ISBN 951-669-607-4 and ISBN 951-628-376-4.

Meklin, Pentti; Kallio, Olavi. Muuttoliikkeen vaikutuksia kuntien talouteen [Effects of migration on the economy of municipalities]. Kuntapuntari, No. 6, 2001, 31-34 pp.

Myrskylä, Pekka. Nuorten työllisyys ratkaisee [The employment of the young is decisive]. Hyvinvointikatsaus, No. 4, 2001, 24-26 pp.

Paasivirta, Anssi. Muuttoliike ja työllisyys: kuusi teesiä muuttoliikkeen ja työllisyyden kehityksestä sekä viisi teesiä aluepolitiikasta [Migration and employment: six theses on the development of migration and employment and five theses on regional policy]. In: Muuttoliikkeet vuosituhannen vaihtuessa - halutaanko niitä ohjata? Muuttoliikesymposium 2000, Turku 22.-24.11., edited by Elli Heikkilä. Siirtolaisuustutkimuksia A, No. 24. 2001. 90-100 pp. Siirtolaisuusinstituutti, Turku. ISBN 951-9266-73-9.

Parkkinen, Pekka. Suomi selviää vanhuusmenoista - mutta entä muuttotappioalueet ?[Finland is coping with the expenses of the old age - but what about the net emigration areas?]. Yhteiskuntapolitiikka, Vol. 67, No. 4, 2002, 346-351 pp.

Nieminen, Mauri. Työttömyys tai pätkätyö - monen maahanmuuttajan kohtalo [Unemployment or short-term work - the fate of many immigrants]. Tietoaika, No. 12, 2002, 12-14 pp.

Parkkinen, Pekka. Hoivapalvelut ja eläkemenot vuoteen 2050 [The health services and pension expenditure until 2050]. VATT-tutkimuksia, No. 94. 2002. $51 \mathrm{pp}$. Valtion taloudellinen tutkimuskeskus, Helsinki. ISBN 951-561-425-2.

Pekkala, Sari. Unemployment and regional migration in Finland. In: Muuttoliikkeet vuosituhannen vaihtuessa - halutaanko niitä ohjata? Munttolilkesymposium 2000, Turku 22.-24.11., 
edited by Elli Heikkilä. Siirtolaisuustutkimuksia A, No. 24. 2001. 267-276 pp. Siirtolaisuusinstituutti, Turku. ISBN 951-9266-73-9.

Rusanen, Jarmo; Muilu, Toivo; Colpaert, Alfred; Naukkarinen, Arvo. Vertailu alueellisista tuloeroista: kun väki vähenee, pidot huononevat [A comparison of regional income differences: the less people, the less income]. Tietoaika, No. 5, 2001, 14-17 pp.

Sabour, M'Hammed. Maahanmuuttajat Euroopassa: syrjäytymisestä kotoutumiseen [Immigrants in Europe: from marginalization to integration]. In: Maahanmuuttaja kahden kulttuurin välissä = invandrare mellan tvă kulturer. 2001. 19-31 pp. Euroopan kulttuurisäätiön Suomen osasto. Helsinki. ISBN 951-8932-15-8.

Vaattovaara, Mari; Vuori, Pekka. Väestörakenteen ja alueellisen eriytymisen vaikutus Helsingin veropohjaan [The effect of the population structure and regional segregation on the tax base of Helsinki]. Tutkimuskatsauksia 2002, No. 1. 2002. 32 pp. Helsingin kaupugin tietokeskus, Helsinki. ISBN 951-718-885-4.

Valkonen, Tarmo. Väestöskenaariot ja julkinen talous [Population scenarios and public economy). Kuntapuntari, No. 6, 2001, 44-47 pp.

Valkonen, Tarmo. Demographic uncertainty and taxes. Keskusteluaiheita, No. 816. 2002. 20 pp. ETLA, Helsinki.

Valkonen, Tarmo. Väestön ikääntyminen ja verotus [Ageing and taxation]. Etla, B, No. 190. 2002. 97 pp. Taloustieto, Helsinki. ISBN 951-628-364-0.

\section{DEMOGRAPHIC AND NONECONOMIC INTERRELATIONS}

Fellman, J.; Eriksson, A.W. Regional, temporal, and seasonal variations in births and deaths: the effects of famines. Social Biology, Vol. 48, No. 1, 2001, 86-104 pp.

Ferrie, J.E.; Martikainen, P.; Shipley, M.J., Marmot, M.G.; Stansfeld, S.; Davey Smith, G. Employment status and health after privatization in white-collar civil servants: prospective cohort study. British Medical Journal, Vol. 322, No. 7287, 2001, 647-651 pp.

Ferrie, J.E.; Shipley, M.J.; Marmot, M.G.; Martikainen, P.; Stansfeld, S.; Davey Smith, G. Job insecurity in white-collar workers: towards an explanation of associations with health. Journal of Occupational Health Psychology, Vol. 6, No. 1, 2001, 26-42 pp.

Haavio-Mannila, Elina; Kontula, Osmo; Kuusi, Elina. Trends in sexual life measured by national sex surveys in Finland in 1971, 1992 and 1999, and a comparison to a sex survey in St. Petersburg in 1996. Working papers E 10/2001. 2001. 309 pp. The Population Research Institute, Väestöliitto, The Family Federation of Finland. ISBN 952-9605-67-6.

Harper, S.; Lynch, J.; Hsu, W.L.; Everson, S.A.; Hillemeier, M.M.; Raghunathan, T.E.; Salonen, J.T.; Kaplan, G.A. Life course socioeconomic conditions and adult psychosocial functioning. International Journal of Epidemiology, Vol. 31, No. 2, 2002, 395-403 pp.

Heistaro, S.; Laatikainen, T.; Vartiainen, E.; Puska, P.; Uutela, A.; Pokusajeva, S.; Uhanov, M. Self-reported health in the Republic of Karelia, Russia and in north Karelia, Finland in 1992. European Journal of Public Health, Vol.11, No.1, 2001, 74-80 pp.

Hyyppä, M.T.; Mäki, J. Individual-level relationship between social capital and self-rated health in bilingual community. Preventive Medicine, Vol. 32, No. 2, 2001, 148-55 pp.

Härö, Sakari A. Väestön terveydentila Suomessa ja muissa EU-maissa [The health of population in Finland and other countries in the European Union]. Suomen Lääkärilehti, Vol. 56, No. 25-26, 2001, 2807-12 pp.

Ishizaki, M.; Martikainen, P.; Nakagawa, H.; Marmot, M. Socioeconomic status, workplace characteristics and plasma fibrinogen level of Japanese male employees. Scandinavian Journal of Work Environment and Health, Vol. 27, No. 4, 2001, 287-91 pp.

Kivelä, K.; Lahelma, E.; Roos, E.; Tuominen, T.; Dahl, E.; Diderichsen, F.; Elstad J.I.; Lissau, I.; Lundberg, O.; Rahkonen, O.; Rasmussen, N.K.; Ảberg Yngwe, M. Sairastavuuden väestöryhmittäiset muutokset Pohjoismaissa 1980-ja 1990-luvulla [The changes in morbidity by population groups in the Nordic Countries in the 1980s and the 1990s]. Suomen Lääkärilehti, Vol. 56, No. 2, 2001, 155-160 pp. 
Klemetti, R.; Gissler, M.; Hemminki, E. Comparison of perinatal health of children born from IVF in Finland in the early and late 1990s. Human Reproduction, Vol. 17, No. 8, 2002, $2192-$ $98 \mathrm{pp}$.

Kuronen, Marjo. Motherhood in family context - comparing professional practices in maternity and child health care in Finland and Scotland. Yearbook of Population Research in Finland, Vol. 37, 2001, 5-22 pp.

Laaksonen, M.; Lahelma, E.; Prättälä, R. Associations among health-related behaviours: sociodemographic variation in Finland. Sozial- und Praventivmedizin, Vol. 47, No. 4, 2002, 225-232 pp.

Lahelma, Eero; Arber, Sara; Martikainen, Pekka; Rahkonen, Ossi; Silventoinen, Karri. The myth of gender differences in health: social structural determinants across adult ages in Britain and Finland. Current Sociology, Vol. 49, No. 3, 2001, 31-54 pp. (Monograph 1, The Sociology of Health and Illness, edited by Eugene B. Callagher and Elianne Riska).

Lahelma, E.; Arber, S.; Kivelä, K.; Roos, E. Multiple roles and health among British and Finnish women: the influence of socioeconomic circumstances. Social Science \& Medicine, Vol. 54, No. 5, 2002, 727-40 pp.

Lahelma, E.; Kivelä, K.; Roos, E.; Tuominen, T.; Dahl, E.; Diderichsen, F.; Elstad, J.I. ; Lissau, I.; Lundberg, O.; Rahkonen, O.; Rasmussen, N.K.; Yngwe, M.A. Analysing changes of health inequalities in the Nordic welfare states. Social Science \& Medicine, Vol. 55, No. 4, 2002, 609-25 pp.

Malin, Maili. Maailma on liikkeessä - maahanmuuttajien terveyskysymykset [The world is on the move - the health issues of the immigrants]. Sosiaaliläaketieteellinen Aikakauslehti, Vol. 39, No. 2, 2002, 83-87 pp.

Manderbacka, K.; Lahelma, E.; Rahkonen, O. Structural changes and social inequalities in health in Finland, 1986-1994. Scandinavian Journal of Public Health, Suppl. Vol. 55, 2001, 41-54 pp.

Martelin, Tuija; Koskinen, Seppo; Kattainen, Anna; Sainio, Päivi; Reunanen, Antti; Aromaa, Arpo. Changes and differentials in the prevalence of activity limitations among Finns aged 65-74: comparison of the Mini-Finland Health Examination Survey (1978-80) and the FINRISK-97 Senior Survey (1997). Yearbook of Population Research in Finland, Vol. 38, 2002, 55-75 pp.

Martikainen, P.; Ishizaki, M.; Marmot, M.; Nakagawa, H.; Kagamimori, S. Sociocconomic differences in behavioural and biological risk factors: a comparison of a Japanese and an English cohort of employed men. International Journal of Epidemiology, Vol. 30, No. 4, 2001, 833$838 \mathrm{pp}$.

Martikainen, P.; Bartley, M.; Lahelma, E. Psychosocial determinants of health in social epidemiology. International Journal of Epidemiology, Vol. 31, No. 6, 2002, 1091-93 pp.

Nivalainen, Satu; Volk, Raija. Väestö ja hyvinvointipalvelut vuonna 2030: alueellinen tarkastelu [Population and welfare services in 2030: a regional analysis]. Sosiaali- ja terveysministeriön julkaisuja, No 15, 2002. 2002. 46 pp. Sosiaali- ja terveysministeriö, Helsinki. ISBN 952-001173-0. Sum in Swe, Eng.

Nivalainen, Satu; Volk, Raija. Väestön ikääntyminen ja hyvinvointipalvelut: alueellinen tarkastelu [Regional aspects of ageing and welfare services]. Pellervon taloudellisen tutkimuslaitoksen raportteja, No. 181. 2002. 199, [6] pp. Pellervon taloudellinen tutkimuslaitos, Helsinki. ISBN 952-5299-52-X. Sum in Eng.

Norio, Reijo; Löytönen, Markku. The Finnish disease heritage. Fennia: International Journal of Geography, Vol. 180, No. 1-2, 2002, 177-182 pp.

Ostamo, A.; Lahelma, E.; Lönnqvist, J. Transitions of employment status among suicide attempters during a severe economic recession. Social Science \& Medicine, Vol. 52, No. 11, 2001, 1741$50 \mathrm{pp}$.

Rahkonen, O.; Lahelma, E.; Martikainen, P.; Silventoinen, K. Determinants of health inequalities by income from the 1980 s to the 1990s. Journal of Epidemiology and Community Health, Vol. $56,2002,442-443$ pp.

Reinhardt Pedersen, C.; Madsen, M. Parents' labour market participation as a predictor of children's health and wellbeing: a comparative study in five Nordic countries. Journal of Epidemiology 
and Community Health, Vol. 56, No. 11, 2002, 861-867 pp.

Roos, E.; Kivelä, K.; Lahelma, E.; Tuominen, T.; Dahl, E.; Diderichsen, F.; Elstad, J.I.; Lundberg, O.; Rahkonen, O.; Rasmussen, N.K.; Yngwe, M.A. Liten förändring av hälsoskillnader i Norden under 1980- och 1990-talen [Small changes in health differences in the Nordic countries during the 1980s and 1990s]. Läkartidningen, Vol. 98, No. 21, 2001, 2576-7, $2580-4 \mathrm{pp}$.

Siirilä, Seppo; Vaattovaara, Mari; Viljanen, Ville. Well-being in Finland: a comparison of municipalities and residential differentiation in two cities. Fennia: International Journal of Geography, Vol. 180, No. 1-2, 2002, 141-149 pp.

Silventoinen, K.; Lahelma, E.; Lundberg, O.; Rahkonen, O. Body height, birth cohort and social background in Finland and Sweden. European Journal of Public Health, Vol. 11, No. 2, 2001, 124-129 pp.

Silventoinen, K.; Lahelma, E. Health inequalities by education and age in four Nordic countries, 1986 and 1994. Journal of Epidemiology and Community Health, Vol. 56, No. 4, 2002, 253-258.

Soininen, L.; Järvinen, S.; Pukkala, E. Cancer incidence among Sami in Northern Finland, 1979-1998. International Journal of Cancer, Vol. 100, No. 3, 2002, 342-346 pp.

Suorsa, Seppo. Katsaus Oulun läänin väestön hyvinvoinnin tilaan v. 2000 [Report on the welfare of the population in the province of Oulu]. Oulun lääninhallituksen julkaisuja, No. 88. 2002. 25, [20] pp. Oulun lääninhallitus, Oulu.

Tammentie, T.; Tarkka, M.T.; Astedt-Kurki, P.; Paavilainen, E. Sociodemographic factors of families related to postnatal depressive symptoms of mothers. International Journal of Nursing Studies, Vol. 8, No. 5, 2002, 240-246 pp.

\section{POLICIES}

Elo, Kalle; Koskinen, Lasse. Hyvä väestöpolitiikka on eläkkeiden maksun kivijalka [Good population policy is the basis of pension payments]. Työeläke, Vol. 36, No. 2, 2001, 8-10 pp.

Hiilamo, Heikki. Perhepolitiikka vedenjakajalla: Suomen ja Ruotsin linjavalinnat 1997-2002 [Family policy at a divide: the policy choices of Finland and Sweden in 1997-2002]. Aiheita, No. 13/2002. 2002.43 pp. STAKES Sosiaali-ja terveysalan tutkimus- ja kehittämiskeskus, Helsinki. ISBN 951-33-1261-5.

Hiilamo, Heikki. Suomalaisen perhepolitiikan pitkä linja: "Akantappolaista" työ- ja perheelämän yhteensovittamiseen [The long journey of Finnish family policy: From the land acquisition law to the reconciliation of working life and family life]. Janus, Vol. 10, No. 3 , 2002, 274-279 pp.

Hiilamo, Heikki. The rise and fall of Nordic family policy? Historical development and changes during the 1990s in Sweden and Finland. Research reports, No. 125. 2002. 399 pp. STAKES National Research and Development Centre for Welfare and Health, Helsinki. ISBN $951-$ 33-1311-5. Doctoral dissertation. Sum in Fin, Swe.

Majava, Altti. Ongelmallinen väestöpolitiikka [Problematic population policy]. In: Artikkeleita Suomen väestöntutkimuksesta: väestötieteen johdantokurssiin liittyvä moniste. Helsingin yliopiston sosiologian laitoksen monisteita, No. 62. 2002. 249-258 pp. Helsingin yliopisto, sosiologian laitos, Helsinki. ISBN 951-45-8265-9.

Nätkin, Ritva. Hyvinvointia perheille - väestöpolitiikka ja naisten toimijuus [Welfare to families - population policy and activity of women]. In: Suomineitonen heil: kansallisuuden sukupuoli, edited by Tuula Gordon, Katri Komulainen, and Kirsti Lempiäinen. 2002. 176-194 pp. Vastapaino, Tampere. ISBN 951-768-107-0.

Pitkänen, Pirkko; Atjonen, Päivi. Kohti aktiivista maahanmuuttopolitiikkaa: kulttuurinen monimuotoisuus Itä-Suomen yrityselämässä [Towards an active immigration policy: cultural diversity in the enterprise life of Eastern Finland]. Karjalan tutkimuslaitoksen julkaisuja, No. 135. 2002. 100 pp. Joensuun yliopisto, Joensuu. ISBN 952-458-133-7. 
Salmi, Minna; Lammi-Taskula, Johanna. Mitä pienten lasten vanhemmat haluavat perhepolitiikalta? [What the parents of small children expect from family policy). Yhteiskuntapolitiikka, Vol. 67, No. 6, 2003, 578-583 pp.

Sisäasiainministeriö [Ministry of the Interior]. Ulkomaalaislakityöryhmän mietintö [Report of a committee on the laws concerning foreigners]. Sisäasiainministeriön julkaisu, No. 12/ 2001. 2001. 274, [89] pp. Sisäasiainministeriö, Helsinki. ISBN 951-734-469-4.

Suurpää, Leena. Hyvää tahtoa vai hyvää vaihtoa? Maahanmuuttajien kotouttamisohjelmat solidaarisuuden valossa [Good will or good exchange? Immigrant integration programmes in the light of solidarity]. Yhteiskuntapolitiikka, Vol. 67, No. 1, 2002, 13-26 pp. Sum in Eng.

Tanni, Katri. Australian asenteellinen siirtolaisuuspolitiikka vuosina 1945-1970: white Australian policy [The prejudiced migration policy of Australia in 1945-1970: white Australian policy]. Siirtolaisuus, Vol. 29, No. 2, 2002, 2-8 pp.

Työministeriö [Ministry of Labour]. Selonteko kotouttamislain toimeenpanosta-projekti: loppuraportti [A report on the execution of the integration law]. 2002. 149, [61] pp. Työhallinnon julkaisu, No. 316. Työministeriö, Helsinki. ISBN 951-735-720-6.

Wallenius, Tapio. Vieraassa vara parempi? Suomen maahanmuuttajapolitiikan haasteet [More labor from abroad? The challenges of the Finnish immigration policy]. $2001.48 \mathrm{pp}$. Taloustieto Oy and EVA, Helsinki. ISBN 951-628-343-8.

Valtioneuvosto [The Finnish Government]. Valtioneuvoston selonteko kotouttamislain toimeenpanosta [The report of the Finnish Government on the execution of the integration law]. 2002. 69 pp. +4 App. Valtioneuvosto, Helsinki.

\section{N. METHODS OF RESEARCH AND ANALYSIS INCLUDING MODELS}

Kannisto, Väinö. Väkiluku- ja väestönmuutostietojen kerääminen kehitysmaissa [Collection of population and vital statistics data in the developing countries]. In: Artikkeleita Suomen väestöntutkimuksesta: väestötieteen johdantokurssiin liittyvä moniste. Helsingin yliopiston sosiologian laitoksen monisteita, No. 62. 2002. 55-59 pp. Helsingin yliopisto, sosiologian laitos, Helsinki. ISBN 951-45-8265-9.

Koskinen, Seppo. Demografiset mittaluvut [Demographic parameters]. In: Artikkeleita Suomen väestöntutkimuksesta: väestötieteen johdantokurssiin liittyvä moniste. Helsingin yliopiston sosiologian laitoksen monisteita, No. 62. 2002. 60-85 pp. Helsingin yliopisto, sosiologian laitos, Helsinki. ISBN 951-45-8265-9.

Pitkänen, Kari. Suomen väestörekisterit ja väestötilastot [Finland's population registers and population statistics]. In: Artikkeleita Suomen väestöntutkimuksesta: väestötieteen johdantokurssiin liittyvä moniste. Helsingin yliopiston sosiologian laitoksen monisteita, No. 62. 2002. 46-54 pp. Helsingin yliopisto, sosiologian laitos, Helsinki. ISBN 951-45-8265-9.

Polvinen, Anu. Stokastisen ennusteen käyttö julkisen talouden kehityksen arvoinnissa [Using stochastic forecasts in the assessment of the development of the public economy]. Raportteja, No. 23. 2001. 58 pp. Eläketurvakeskus, Helsinki. ISBN 952-9639-86-4.

\section{O. THE PRODUCTION OF POPULATION STATISTICS}

Tilastokeskus [Statistics Finland]. Väestölaskenta 2000 [Census 2000]. Käsikirjoja, No. 35. 2001. 53 pp. Tilastokeskus, Helsinki. ISBN 951-727-934-5. Published also in English and Swedish. 


\section{P. PROFESSIONAL MEETINGS AND CONFERENCES}

Heikkilä, Elli (ed.). Muuttoliikkeet vuosituhannen vaihtuessa - halutaanko niitä ohjata? Muuttoliikesymposium 2000, Turku 22.-24.11. [Migration at the turn of the century - is it wanted to be controlled? Migration symposium 2000, Turku, November 22-24.]. Siirtolaisuustutkimuksia A, No. 24. 2001.311 pp. Siirtolaisuusinstituutti, Turku. ISBN 951-9266-73-9.

[Söderling, Ismo] (ed.). European Population Conference, Helsinki, Finland 7-9 June, 2001: Abstracts. Helsinki: The Family Federation of Finland/Väestöliitto. 2001. 292 pp. (Organizers of the Conference: EAPS European Association for Population Studies, The Family Federation of Finland/Väestöliitto, Statistics Finland, The Demographic Society of Finland). ISBN 952-9605-71-4.

Takoja, Mika; Pakarinen, Mari; Söderling, Ismo (ed.). Papers of the European Population Conference, Helsinki, June 6-9, 2001. 2001. Organizers: EAPS (European Association for Population Studies), Väestöliitto, The Family Federation of Finland, Statistics Finland, and The Finnish Demographic Society. Available at

$<$ http://www.vaestoliitto.fi/toimintavksikot/vaestontutkimuslaitos/eapskonferenssi/papers.html $>$. ISBN 952-9605-76-5 (PDF).

\section{Q. BIBLIOGRAPHIES, DIRECTORIES AND OTHER INFORMATION SERVICES}

Mattila, Ulla-Maija. Bibliography of Finnish population studies 2000. Yearbook of Population Research in Finland, Vol. 37, 2001, 148-166 pp.

\section{R. NEW PERIODICALS}

(No citations)

\section{S. OFFICIAL STATISTICAL PUBLICATIONS}

\section{Official Statistics of Finland, Statistics Finland, Helsinki}

Causes of death

Kuolemansyyt 1999 = causes of death. Health 2001, No. 3. 2001. 119 pp. In Fin, Eng. ISBN 951-727-950-7.

Kuolemansyyt 2000 = causes of death. Health 2002, No. 1. 2002. 119 pp. In Fin, Eng. ISBN 951-467-022-4.

Kuolemansyyt $2001=$ dödsorsaker $=$ causes of death. Health 2002, No. 3. 2002. 121 pp. In Fin, Swe, Eng. Health 2002, No. 3. ISBN 951-467-110-7.

\section{Censuses}

Rakennukset, asunnot ja asuinolot $2000=$ byggnader, bostäder och boendeförhållanden = buildings, dwellings and housing conditions. Housing 2001, No. 9. 2001. 198 pp. In Fin, Swe, Eng. ISBN 951-727-983-3.

Työssäkäyntitilasto 1999-2000 = sysselsättningstatistik = employment statistics. Population 2002, No. 3. 2002. 341 pp. In Fin, Swe, Eng. ISBN 952-467-013-5. 
Economic activity

Työssäkäyntitilasto 1998-1999 = sysselsättningsstatistik [Employment statistics]. Väestö 2001, No. 2. 2001.354 pp. In Fin, Swe. ISBN 951-727-865-9.

Families

Kartovaara, Leena. Children in Finland. Population 2001, No. 9. 2001. 208 pp. ISBN 951-727-928-0.

Perheet $2000=$ familjer $=$ families. Population 2001, No. 12. 2001. 168 pp. In Fin, Swe, Eng. ISBN 951-727-975-2.

Perheet $2001=$ familjer $=$ families. Population 2002, No. 10. 2002. 163 pp. In Fin, Swe, Eng. ISBN 952-467-105-0.

\section{Migration}

Ulkomaalaiset ja sirtolaisuus $=$ foreigners and international migration 2000. Population 2000, No. 8. 2001. 58 pp. In Fin, Eng. ISBN 951-727-948-5.

Ulkomaalaiset ja siirtolaisuus $=$ foreigners and international migration 2001. Population 2002, No. 8. 2002. 70 pp. In Fin, Eng. ISBN 952-467-100-X

Population size

Väkiluku kunnittain ja suuruusjärjestyksessä 31.12.2000 = befolkning kommunvis och $i$ storleksordning 31.12.2000 [Population by municipality and by the size of population in municipalities on December 31, 2000]. Population 2001, No. 3. 2002. 28 pp. In Fin, Swe. ISBN 951-727-867-5.

Väkiluku kunnittain ja suuruusjärjestyksessä 31.12.2001 = befolkning kommunvis och $i$ storleksordning 31.12.2001 [Population by municipality and by the size of population in municipalities on December 31, 2001]. Population 2002, No. 2. 2002. 36 pp. In Fin, Swe. ISBN 951-727-998-1.

Population structure

Väestörakenne $2000=$ befolkningens sammansättning = population structure. Population 2001, No. 6. 2001. 180 pp. In Fin, Swe, Eng. ISBN 951-727-912-4.

Väestörakenne $2001=$ befolkningens sammansättning $=$ population structure. Population 2002, No. 6. 2002. 174 pp. In Fin, Swe, Eng. ISBN 951-767-050-X.

\section{Vital statistics}

Väestönmuutokset $2000=$ befolkningsförändringar $=$ vital statistics. Population 2001, No. 13. 2001. 154 pp. In Fin, Swe, Eng. ISBN 951-727-980-9.

Väestönmuutokset kunnittain $2000=$ befolkningsförändringar kommunvis $=$ vital statistics by municipality. Population 2001, No. 5. 2001. 64 pp. In Fin, Swe, Eng. ISBN 951-727-904-3.

Väestönmuutokset kunnittain 2001 = befolkningsförändgringar kommunvis = vital statistics by municipality. Population 2002, No. 5. 2002. 65 pp. In Fin, Swe, Eng.

ISBN 952-467-059-6.

\section{Quarterly vital statistics}

Väestön neljännesvuositilasto $=k$ vartalsstatistik över befolkning [Quarterly vital statistics]. Väestö 2000, No. 4 - Väestö 2003, No. 1. (Covering the years 2001 and 2002). In Fin, Swe.

Population statistics and projections by other institutions

Gissler, Mika; Vuori, Eija; Rasimus, Anja; Ritvanen, Annukka. Lisäantymistilastot $2000=$ reproduktionsstatistik $2000=$ reproduction statistics 2000. Tilastoraportti, No. 3/2001. 
2002. 171 pp. STAKES Sosiaali- ja terveysalan tutkimus- ja kehittämiskeskus, Helsinki. ISBN 951-33-1133-3.

Miettinen, Anneli. Population data on Finland 1900-2000. Yearbook of Population Research in Finland, Vol. 37, 2001, 167-174 pp.

Miettinen, Anneli. Population data on Finland 1900-2000. Yearbook of Population Research in Finland, Vol. 38, 2002, 220-227 pp.

Väestörekisterikeskus [Population Register Centre]. Suomen asukasluku: vuodenvaihde 2000$2001=$ Finlands invånartal: årskiftet 2000-2001 [The size of the Finnish population: turn of the year 2000-2001]. 2001. 36 pp. + CD-ROM. Helsinki.

Väestörekisterikeskus [Population Register Centre]. Suomen asukasluku: vuodenvaihde 20012002 = Finlands invånartal: årskiftet 2001-2002 [The size of the Finnish population: turn of the year 2001-2002]. 2002. 33 pp. + CD-ROM. Helsinki.

\section{Sources}

ARTO Reference Database of Finnish Articles, accessed on April 7, 2003

FENNICA National Bibliography of Finland, accessed on April 3, 2003

LINDA Database of Finnish University Libraries, accessed on April 10, 2003

Medline database $\leq$ http://www.ncbi.nlm.nihgov/entrez/query $>$, accessed on April 4, 2003

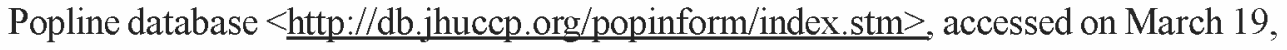
2003

Publications of the Population Research Unit, Department of Sociology, University

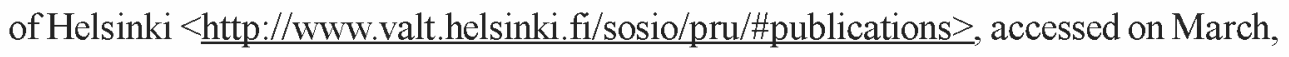
14,2003

Sociological Abstracts database, accessed on April 7, 2003

The collections of the library of the Population Research Institute of Väestöliitto, Helsinki.

\section{Author Index}

Adachi, H. - E

Ahmad, Akhlaq - K

Albanes, D. - E

Alfredsson, L. - E

Alho, Juha M. - D, E

Alho, Kari - K.

Ali, Abdullahi - J

Alitolppa-Niitamo, Anne - H1, J

Andersen, A.G. - F

Andreev, Evgueni M. - J

Anttonen, Marjut - $\mathrm{Hl}$, J

Arber, S. - L

Arber, Sara - L
Aromaa, A. - E

Aromaa, Arpo - E, L

Arstila, M. - E

Arstila, Matti - E

Astedt-Kurki, P. - L

Atjonen, Päivi - M

Auger, S. - F

Barlow, L. - E

Bartley, M. -L

Begun, Alexander - J

Beijbom, Ulf - H1

Blackburn, H. - E

Bobak, M. - E 
Brunner, E.- J

Böckerman, Petri - H2

Cawood, E.H. - F

Colpaert, Alfred - D, K

Dahl, E. - L

Davey Smith, G. -L

Diderichsen, F. - L

Drevenstedt, Greg L. - E

Edvardsson, Ingi Runar - K

Ekholm, Elina - J, K

Elo, Irma - E

Elo, Kalle - M

Elstad, J.I. - L

Enckell, Maria Jarlsdotter - H1

Eriksson, A.W. - L

Eustache, F. - F

Edvardsson, Ingi Runar - K

Everson, S.A. - L

Falck, Winther J. - E

Fellman, J. - L

Ferrie, J.E. - L

Feskens, E. - E

Feskens, E.J. - E

Finnäs, Fjalar - G, J

Forsander, Annika - H1, J, K

Furher, R. - J

Garwicz, S. - E

Giampaoli, S. - E

Gissler, Mika - L, S

Glattre, E. - E

Greijus, Sari - K

Haapanen, Mika - H2, J

Haavio-Mannila, Elina - L

Hagström, U. - E

Hakko, H. - E, G

Hallenberg, Tanja - H1

Hammar, N. - E

Hammar, T. - E

Harper, S. - L

Harviainen, Tapani - J

Heikkilä, Elli - H1, H2, K

Heikkilä, Elli (ed.) - P

Heikkilä, K. - E
Heistaro, S. - E, L

Heliövaara, Markku - E

Hemminki, E. - L

Hiilamo, Heikki - M

Hillemeier, M.M. - L

Hintikka, Jukka - J

Hirvonen, Martti - C

Hjerppe, Reino - H1

Honkanen, Ossi - D, J

Honkanen, R. - E

Hsu, W.L. - L

Hunnakko, Pekka - H2

Hyyppä, M.T. - J, L

Hämynen, Tapio - G

Hämäläinen, Kari - H2

Härö, Sakari - L

Ikonen, Niina - E

Immonen-Raiha, P. - E

Immonen-Räihä, Pirjo - E

Irvine, S. - F

Ishizaki, M. - L

Iskanius, Sanna - J

Isohanni, M.K. - E

Jalovaara, Marika - G

Jensen, T.K. - F

Johansson, Mats - K

Jokelainen, J. - E, G

Joronen, Tuula - K

Jouannet, P. - F

Joukamaa, M. - E

Joukamaa, M.I.- E

Jousilahti, P. - E

Jutikkala, Eino - $\mathrm{H} 2$

Järvelin, M.R. - E, G

Järvinen, S. - L

Järvinen, Tero - J

Jörgensen, N. - F

Kaarsalo, E. - E

Kaarsalo, Esko - E

Kagamimori, S. - L

Kainulainen, Sakari - G, H2

Kalland, M. -E

Kallio, Olavi - H2, K 
Kannisto, Väinö - J, M

Kaplan, G.A. - L

Kaprio, J. - E

Karjalainen, A. - E

Karni, Michael G. - Hl

Kartovaara, Leena - G

Kataja, Jukka-Pekka - H2

Katajala, Kimmo - G

Katajala-Peltomaa, Sari - G

Kattainen, Anna - L

Kauppinen, Jarkko - H2

Kauppinen, Timo - J

Kauppinen, Timo M. - E

Keiding, N. - F

Keränen, Heino - D

Keränen, Sirpa - D

Ketonen, M. - E

Ketonen, Matti - E

Kilponen, Juha - K

Kinnunen, Helvi - K

Kirkas, Tiina (ed.) - H1

Kivelä, K. - L

Kivisto, Peter - H1

Klaukka, Timo - E

Kleemola, Marjaana - E

Klemetti, R. - L

Knekt, P. - E

Knekt, Paul - E

Koivumaa-Honkanen, H. - E

Koivumaa-Honkanen, Heli-Tuulie - J

Konttajärvi, Tiina - $\mathrm{H} 2$

Kontula, Osmo - E, J, L

Korhonen, Sirpa - D, K

Korkalainen, Sari - H1

Korkiasaari, Jouni - H1

Korpela, Heikki - E

Koskela, Kaj - J

Koskela, Tarja - J

Koskenvuo, M. - E

Koskinen, Lasse - M

Koskinen, O. - G

Koskinen, S. - E

Koskinen, Seppo - E, L, M
Kostiainen, Auvo - $\mathrm{Hl}$

Kosunen, E. - F

Kosunen, Elise - F

Kromhout, D. - E

Kultalahti, Olli - H1, H2, K

Kuronen, Marjo - L

Kuulasmaa, K. - E

Kuulasmaa, Kari - E

Kuusi, Elina - L

Kyntäjä, Eve - J

Laakso, Seppo - H2

Laaksonen, M. - L

Laatikainen, T. - L

Lahelma, E. - E, L

Lahelma, Eero - L

Lahti-Argutina, Eila - Hl

Laine, Antti - J

Lammi-Taskula, Johanna - M

Lankinen, Markku - H1, H2

Lanti, M. - E

Lassila, Jukka - K

Lehti, Martti - H1

Lehtinen, V. - E

Lehto, S. - E

Lehto, Seppo - E

Leppänen, K. - E

Lintunen, Petri - H2

Lissau, I. - L

Lundberg, O. - L

Lunetta, P. - E

Luukko, Juha - H2

Lynch, J. - L

Lönnqvist, J. - E, L

Löytönen, Markku - L

Maatela, Jouni - E

Madsen, M. - L

Mahonen, M. - E

Majava, Altti - D, H1, M

Malin, Maili - L

Maliranta, Mika - $\mathrm{H} 2$

Manderbacka, K. - L

Marmot, M. - E, J, L

Marmot, M.G. - L 
Martelin, T. - E

Martelin, Tuija - E, L

Martikainen, Jukka-Pekka - H2

Martikainen, P. - E, J, L

Martikainen, Pekka - E, L

Mathur, Ajeet - B

Mattila, Heikki S. - Hl

Mattila, Ulla-Maija - Q

Mein, G. - J

Meklin, Pentti - H2, K

Mella, Ilkka - D

Menotti, A. - E

Meriläinen, J. - E

Meskus, Mianna - F

Miettinen, Anneli - J, S

Miettinen, H. - E

Miettinen, Heikki - E

Mikkonen, Kauko - D

Moring, Beatrice - $\mathrm{G}$

Muilu, Toivo - D, K

Mulder, I. - E

Murphy, M. - E

Myrskylä, Pekka - C, D, H2, K

Mustaniemi, H. - E

Mustaniemi, Harri - E

Mähönen, Markku - E

Mäkelä, P. - E

Mäki, J. - J, L

Möller, T.R. - E

Nakagawa, H. - L

Naukkarinen, Arvo - K

Nenonen, Tuomo - H2

Neubauer, Jörg - H1

Nevalainen, Pekka - H1

Nguen, Cuong Quoc - J

Niemela, M. - E

Niemelä, Matti - E

Nieminen, Mauri - H2, K

Nissinen, A. - E

Nivalainen, Satu - H2, J, L

Norio, Reijo - A, L

Notkola, I.-L. - E, F

Notkola, Veijo - E
Nurminen, M. - E

Nätkin, Ritva - M

Näyhä, S. - E

Olafsdottir, G. - E

O'Leary, Richard - G

Olsen, J.H. - E

Ostamo, A. - E, L

Ovaska, Esko - H2

Paajanen, Pirjo - F

Paasivirta, Anssi - K

Paavilainen, E. - L

Pakarinen, Mari (ed.) - P

Palm, Jarmo - H2

Palomaki, P. - E

Palomäki, Pertti - E

Parkkinen, Pekka - D, Hl, K

Pehkonen, Aini - H2

Pekkala, Sari - K

Pelkonen, M. - E

Pensola, T. - E

Pensola, T.H. - E

Penttilä, A. - E

Perfekt, R. - E

Persson, Lars Olof - Hl, K

Pikhart, H. - E

Pitkänen, Kari - A, D, E, M

Pitkänen, Pirkko - M

Poikolainen, K. - E

Poikolainen, Kari - E

Pokusajeva, S. - L

Polvinen, Anu - M

Prättälä, R. - L

Pukkala, E. - L

Puska, P. - E, L

Puska, Pekka - E

Pyhälä, Reijo - E

Pyorala, K. - E

Pyörälä, Kalevi - E

Pöllä, Matti - G

Raghunathan, T.E. - L

Rahkonen, O. - L

Rahkonen, Ossi - L

Raitasalo, R. - E 
Rajaniemi, Jere - J

Rantala, Olavi - D, K

Rasimus, Anja - S

Rasmussen, N.K. - L

Rastas, Merja - J

Reinhardt Pedersen, C. - L

Reunanen, Antti - E, L

Rimpelä, A. - F

Rimpelä, M. - F

Ripatti, S. - E

Ritsilä, Jari - C, H2

Ritvanen, A. - E

Ritvanen, Annukka - S

Roinila, Mika - J

Romppanen, Antti - K

Roos, E. - L

Rose, R. - E

Rostila, Timo - E

Ruokolainen, Anne - F

Rusanen, J. - E

Rusanen, Jarmo - D, K

Rytkönen, M. - E

Ryymin, Teemu - Hl

Räisänen, Tarja - G, J

Räsänen, P. - E, G

Räsänen, P.K. - E

Saarela, Jan - J

Saari, Matti - E, H2

Sabour, M'Hammed - K

Sainio, Päivi - L

Salmi, Minna - M

Salminen, Heikki - H1

Salo, Mikko A. - E

Salomaa, V. - E

Salomaa, Veikko - E

Salonen, J.T. - L

Sankila, R. - E

Sarjakoski, Matti - E

Sarna, S. - E

Sarvimäki, Anneli - J

Sauli, Hannele - G

Sauvola, A. - E, G

Sauvola, Anu - G
Shipley, M.J. - L

Shkolnikov, Vladimir M. - J

Siikala, Jukka (ed.) - H1

Siirilä, Seppo - L

Siitonen, Pentti - H2

Silventoinen, K. - L

Silventoinen, Karri - L

Sinkkonen, J. - E

Sisäasiainministeriö - B, M

Skakkebaek, N.E. - F

Slama, R. - F

Snellman, Hanna - H1

Soininen, L. - L

Spira, A. - F

Stambøl, Lasse Sigbjørn - K

Stansfeld, S.A. - J

Stansfeld, S. - L

Statistics Finland - S

Suominen, J. - F

Suorsa, Seppo - L

Suurpää, Leena - M

Säävälä, Minna - F

Söderling, Ismo - H1, H2, J

Söderling, Ismo (ed.) - P

Takoja, Mika (ed.) - P

Tammentie, T. - L

Tanni, Katri - M

Tarkka, M.T. - L

Tervahauta, M. - E

Tervahauta, Risto, - E

Tervo, Hannu - H2

Tiihonen, J. - E

Tilastokeskus - $\mathrm{O}$

Tohmo, Timo - $\mathrm{H} 2$

Toivanen, Reetta - J

Toppari, J. - F

Torppa, J. - E

Torppa, Jorma - E

Tukiainen, H. - E

Tulinius, $\mathrm{H}$. $-\mathrm{E}$

Tuomilehto, J. - E

Tuomilehto, Jaakko - E

Tuominen, T. - L 
Tuominen, Ville-Mikael - D

Turpeinen, Oiva - E, Hl, I

Työministeriö - H1, M

Uhanov, M. - L

Uutela, A. - L

Vaattovaara, Mari - C, K, L

Valkonen, T. - E

Valkonen, Tapani - E, J

Valkonen, Tarmo - K

Wallenius, Tapio - M

Valtioneuvosto - D, M

Vanttaja, Markku - J

Vartiainen, E. - E, L

Wester, Holger - H1

Westerholm, John - A

Vesterinen, Pentti - H1

Vierula, M. - F

Vihriälä, Vesa - H2

Viinamäki, H. - E

Viinamäki, Heimo - J

Vikat, A. - F

Vikat, Andres - F

Viljanen, Ville - L

Vilmusenaho, Risto - H1

Virtamo, J. - E

Virtanen, Ari - E

Volk, Raija - H2, L

Vuolanto, Ville - G

Vuorenmaa, T. - E

Vuorenmaa, Tapio - E

Vuori, E. - E

Vuori, Eija - S

Vuori, Erkki - E

Vuori, Pekka - K

Väestörekisterikeskus - S

Väänänen, Maarit - H2

Ylikarjula, Simo - J

Ylänkö, Maaria - Hl

Yngwe, M.A. - L

Åberg Yngwe, M. - L

May 12, 2003 